\title{
New species and nomenclatural changes in Cynorkis (Orchidaceae) from Madagascar, the Comoros and the Mascarenes
}

\author{
Johan Hermans ${ }^{1,2}$, Landy Rajaovelona ${ }^{3}$, Phillip Cribb ${ }^{1}$, Jean-Michel Hervouet ${ }^{4}$, Anton Sieder $^{2}$ \& \\ Jacky Andriantiana ${ }^{5}$
}

Summary. Four new species, Cynorkis kiehnii, C. marianneae, C. marmorata and C. murex, are described for the first time. Cynorkis frappieri and C. raymondiana are compared, with the latter reduced to a synonym of the former. Cynorkis gaesiformis, C. galeata, C. nutans and C. stenoglossa are compared and considered one variable species, with the name C. nutans having priority. Additional information is provided about C. mammuthus following the discovery of living material in $\mathrm{N}$ Madagascar.

Key Words. Descriptions, distribution, IUCN Red List assessments, taxonomy, types.

\section{Introduction}

The genus Cynorkis Thouars (Orchidaceae: Orchidoideae) currently comprises around 200 species, subspecies and varieties in total, 183 of which are largely endemic to Madagascar and the surrounding islands (Mascarenes, Comoros), and fewer than 20 species are restricted to mainland Africa (Govaerts et al. 2019). Since the major work on the orchid flora of Madagascar by Schlechter (1924) and Perrier de la Bâthie (henceforth Perrier) (1939), when 78 species were recognised, a number of novelties in the genus have been described from the region by ToilliezGenoud \& Bosser (1961, 1962), Bosser \& Veyret (1970), Bosser (1969, 1980, 1998, 2002, 2015), Hermans \& Cribb (2007, 2014) and Hermans et al. (2007, 2017).

\section{Materials \& Methods}

As part of ongoing research and fieldwork on the orchid flora of Madagascar at the Royal Botanic Gardens Kew, the University of Vienna and PBZT Antananarivo, specimens of putative new taxa were compared with descriptions, herbarium material and drawings of all the type specimens of the genus to ascertain their novelty. This has resulted in the recognition of a number of new species and a better understanding of the nomenclature of others.

The conservation status of the new species given in this paper are summaries of the full IUCN Red List assessments which will be completed and submitted for review and publication by IUCN once the species names are validly published and therefore available for assessment. All the assessments have been compiled based on current knowledge of these taxa, by one of the authors (Landy Rajaovelona), who is an IUCN Red List assessor, using the IUCN Red List Categories and Criteria (2012).

\section{New Species}

Cynorkis kiehnii Hermans, Sieder E $\mathcal{O}$ Prehsler sp. nov. Type: Madagascar, Mahajanga prov., Bealanana area, 1227 m, 31 Jan. 2018, Gamisch, Sieder, Prehsler Eे Andriantiana 7586 (holotype WU!).

http://www.ipni.org/urn:lsid:ipni.org:names:77211716-1

Erect lithophytic herb up to $45 \mathrm{~cm}$ high including the inflorescence. Tubers $1-2$, elongate, ovoid $(15-25 \times 6$ - $9 \mathrm{~mm}$ ), clustered, surface velvety; roots slightly hairy, fleshy, wiry, emerging from the base of the new growth, c. $1.5 \mathrm{~mm}$ in diam. Stem up to $3.5 \mathrm{~cm}$, c. $4 \mathrm{~mm}$ in diam., enveloped by an acuminate sheath, white spotted with lavender-pink, $30 \times 4.3 \mathrm{~mm}$. Leaves $1-2$, erect to arching, longly lanceolate, conduplicate, acuminate, somewhat fleshy, a little shiny on top, up to $16 \times 1.5 \mathrm{~cm}$, pale green with the veins darker, spotted with brownish-pink, base white spotted lavender-pink. Inflorescence erect, emerging from the leaf axil, up to 34

\footnotetext{
Accepted for publication 21 November 2019. Published online 9 December 2020

1 Herbarium, Royal Botanic Gardens, Kew, Richmond, Surrey, TW9 3AE, UK. e-mail: j.hermans@kew.org

2 Core Facility, Botanical Garden, University of Vienna, Rennweg 14, 1030 Vienna, Austria.

3 Kew Madagascar Conservation Centre, Lot II J 131 Ambodivoanjo, Ivandry, Madagascar.

461 rue du Lieutenant Ricard, Chatou, France.

5 Parc Botanique et Zoologique de Tsimbazaza, Rue Fernand Kasanga, Tsimbazaza, Antananarivo, Madagascar.
} 
$\mathrm{cm}, 1.8-2.1 \mathrm{~mm}$ in diam., pale green spotted brownish-pink, glabrous at the base, becoming finely pubescent towards the apex, sometimes with a long leaf-like lanceolate-subulate sheath in the lower half, $45-52 \mathrm{~mm}$ long, $5-8 \mathrm{~mm}$ wide, with a second and third peduncle sheath further up, of the same shape but shorter, $21-24 \mathrm{~mm}$ long, $2-3 \mathrm{~mm}$ wide. Rachis loosely racemose, with $1-3$ flowers. Floral bracts reddish-brown spotted purple, ovate-lanceolate, acuminate, $7-8.5 \mathrm{~mm}$ long, $1.7-1.9 \mathrm{~mm}$ wide. Pedicel with ovary densely hirsute, pale brownish-red, flecked longitudinally with purple-red, almost straight to arching, $22-27 \times 1.8-2.3 \mathrm{~mm}$ in diam. Flowers c. $3 \mathrm{~cm}$ long, $3.3 \mathrm{~cm}$ wide not including the spur, overall white more or less tinted purple-pink, lateral sepals and petals pale, dorsal sepal darker with the veins more intense, lip becoming darker towards the tip, column white, spur pale brownish-red. Dorsal sepal ovate, $10.1-10.4 \times 4.1-4.4 \mathrm{~mm}$, forming a hood with the petals over the column, strongly gibbose, the apex recurved, the base finely pubescent. Lateral sepals spreading, ovate-spathulate, $10.2-10.5 \times 6.6-6.8$ $\mathrm{mm}$, slightly concave, the margins involute, the apex auriculate and reflexed. Petals broadly falcate, 8.8 -9.1 $\times 2.4-2.6 \mathrm{~mm}$, appressed to the inside of the dorsal sepal margins. Lip entire, narrowly lanceolate, 14.7 $14.9 \times 2.7-2.9 \mathrm{~mm}$, with the base shortly auriculate, attenuate, very strongly recurved in the apical half, margins strongly incurved, the base with a short rounded ridge; spur lengthening as the flowers develop, slightly infundibuliform at the base and parallel with the ovary, then pendent, subulate, the apical third a little thickened and flattened, in mature flowers $35-39 \times 1.8-2.9 \mathrm{~mm}$. Column in a horizontal to angular plane $11-14 \mathrm{~mm}$ long, $5-6.5 \mathrm{~mm}$ wide, with two long rostellum arms for over half its length, each with a rounded side-lobe for half the length, staminodes underlying the side lobes forming ovate auricles, a large nose-like mid-lobe, anther loculi elongate, longer than wide, narrowed at the base. Pollinia including the long caudicle c. $11 \mathrm{~mm}$ long. Fruit fusiform with raised ridges, verrucose $35 \times 3 \mathrm{~mm}$. Figs 1, 2.

RECOGNITION. With its entire mid-lobe of the rostellum and two long arms, each with a rounded side-lobe Cynorkis kiehnii belongs in section Gibbosorchis H.Perrier ex Hermans (Hermans et al. 2007: 290). It is recognised by its long lanceolate leaves, a large leaf sheath, a tall 1 - 3-flowered inflorescence, and glabrous flowers with a densely hirsute ovary, an entire strongly incurved lip, a spur subulate in the middle and the apical half thickened and flattened, and long divided rostellum arms. It is undoubtedly very close to but also very different from two Cynorkis described recently from the same area: C. mammuthus Hermans \& P.J.Cribb (Hermans et al. 2017: 13) and
C. elephantina Hermans, Andriant. \& Sieder (Hermans et al. 2017: 7) (compared in Table 1). They share the entire lip, hirsute ovary and column shape but C. kiehnii differs from the former by the fewer flowers almost a third the size, the broader petals, the narrowly lanceolate lip (vs broadly oblanceolate) and the differently shaped spur which is subulate in the middle and the apical half thickened and flattened (vs subulate) along its length. It differs from C. elephantina in particular by its fewer elongate lanceolate leaves (vs obliquely lanceolate), $1-3$ flowers (vs $15-22$ ), the flowers that are about $1 / 3$ smaller with a spur that is about half the length and subulate in the middle with the apical half thickened and flattened (vs subulate along its entire length), and its purple-pink tinted whitish flowers (vs ivory-white spotted with burgundy). DISTRIBUTION. Known only from the Bealanana area in northern Madagascar.

SPECIMENS EXAMINED. MADAGASCAR. Mahajanga prov., Bealanana area, 1227 m, Jan. 2018, Gamisch, Sieder, Prehsler $\mathcal{E}$ Andriantiana 7586 (holotype WU!).

HABITAT. On top of inselberg, on basalt rock in a thin layer of moss, also in cracks in the rock, growing with Nematostylis anthophylla (A.Rich. ex DC.) Baill. (Baillon 1879: 198) (Rubiaceae) and Cynorkis siederi Hermans \& Andriant. (Hermans et al. 2017: 18). 1200 - $1250 \mathrm{~m}$.

CONSERVATION STATUS. Cynorkis kiehnii is only known from a single unprotected locality on top of inselbergs in Sofia region, Mahajanga province. It was found alongside a road and such fragments are known to be particularly at risk from human development. The species is assessed as Critically Endangered CR based on Criterion D, with the number of mature individuals likely to be fewer than 50 (around 20 plants were found on a single inselberg), and under criterion $\mathrm{B} 2 \mathrm{ab}(\mathrm{i}, \mathrm{ii}, \mathrm{iii})$ with a continuing decline in the value of the $\mathrm{AOO}$ and the EOO estimated to be less than $10 \mathrm{~km}^{2}$ and the habitat quality due to human activities such as land clearing and fire for agricultural uses.

FLOWERING TIME. January - February.

ETYMOLOGY. The name honours Dr Michael Kiehn; the inspiring Professor of Botany and Director of the Department of Biogeography and the Botanical Garden, University of Vienna.

Cynorkis marianneae Hermans sp. nov. Type: Madagascar, Antananarivo prov., Ankazobe area, along $\mathrm{RN} 4$, in grass verge, in shade beneath a pine copse, Jan. 1996, Hermans 8135. (holotype K!).

http://www.ipni.org/urn:lsid:ipni.org:names:77211717-1

Erect, single-leafed herb c. $20 \mathrm{~cm}$ tall. Tubers $2-3$, elongate, clustered, surface velvety; roots villous, fleshy, wiry c. $1 \mathrm{~mm}$ in diam. Stem short, $1.5 \mathrm{~cm}$ long, 


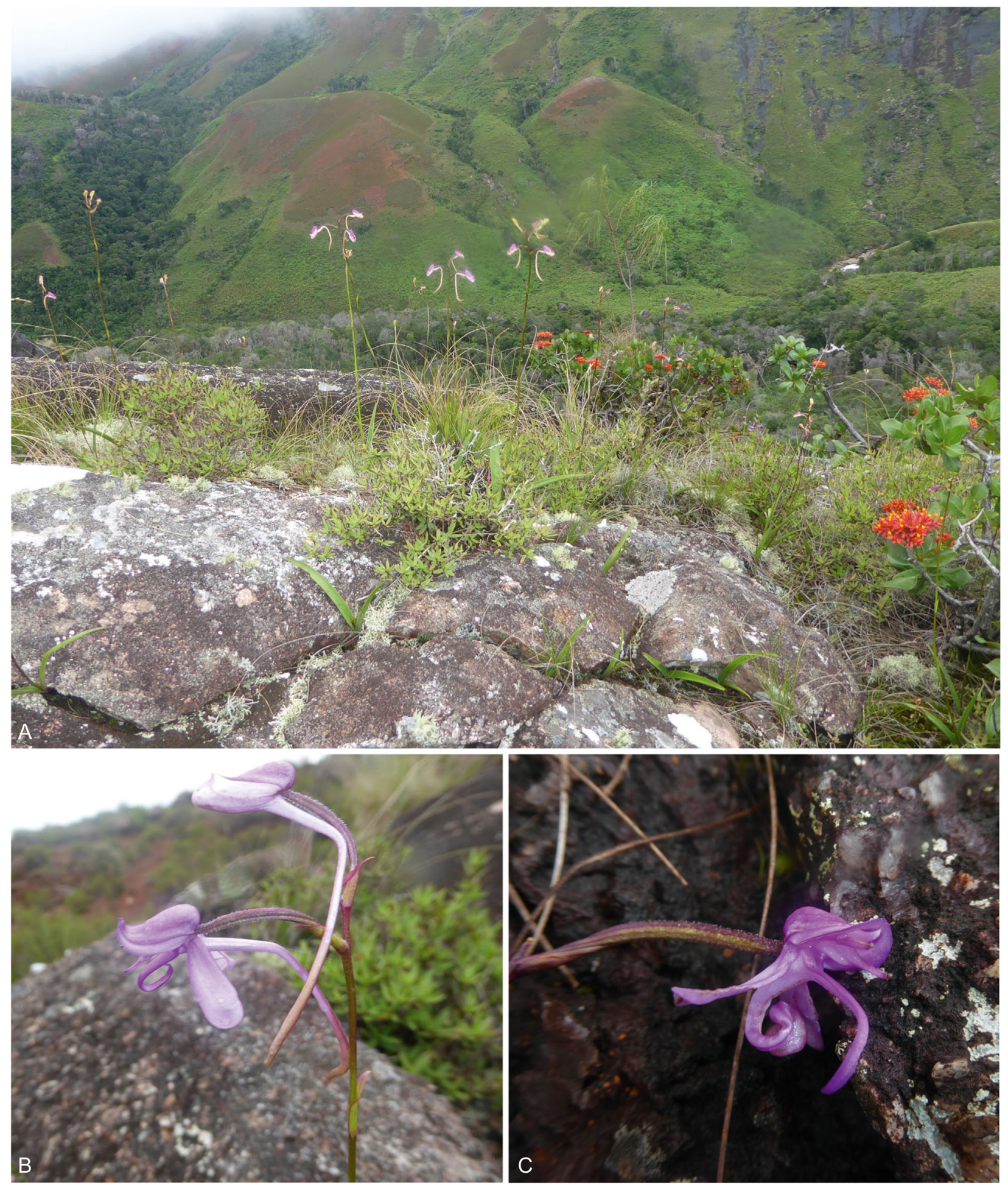

Fig. 1. Cynorkis kiehnii. A plants in habitat; B flower, lateral view; C detail of flower. PHOTOS: ANTON SIEDER.

enveloped by a membranous sheath, $8 \mathrm{~mm}$ in diam. Leaf elongate, ligulate-linear, $12.5 \times 1.3 \mathrm{~cm}$, somewhat fleshy, solitary, pale green. Inflorescence glabrous, up to $13 \times 0.1 \mathrm{~cm}$, arching, with a short membranous sheath at the base and then towards the middle a $32 \times 3 \mathrm{~mm}$ leaf-like sheath, caudate at the apex. Rachis racemose, lax, with $3-4$ flowers. Floral bracts narrowly lanceolate, av. $15 \times 3 \mathrm{~mm}$, becoming shorter towards the apex. Flowers $2.5 \times 1.5 \mathrm{~cm}$, with pale olive green petals and sepals, a white lip with a crimson purple base, 

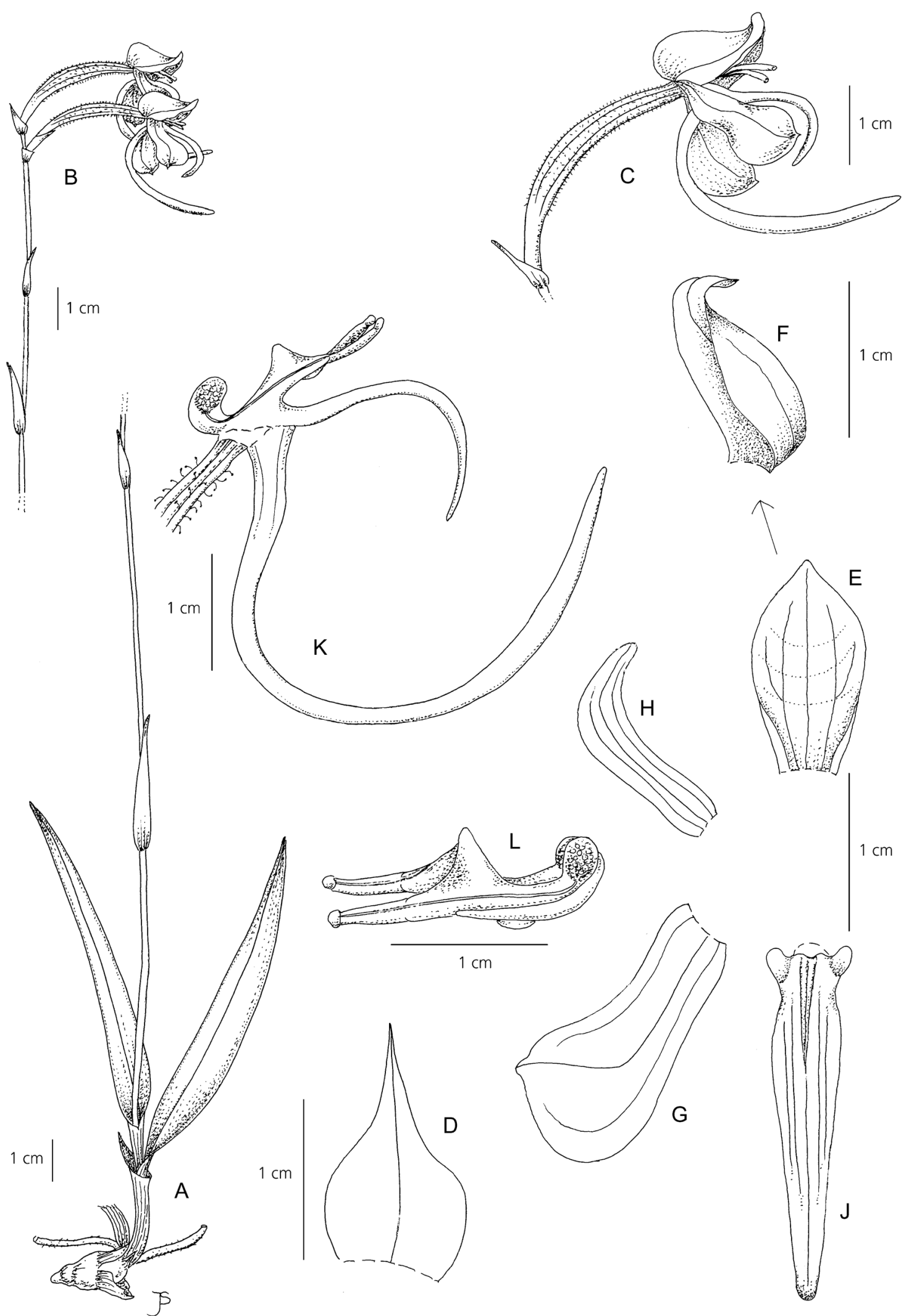

Fig. 2. Cynorkis kiehnii. A habit; B inflorescence; C flower; D floral bract; E dorsal sepal, front view; F dorsal sepal, oblique view; G lateral sepal; H petal; J lip; K column and lip, side view; L column, side view. From Gamisch, Sieder, Prehsler \& Andriantiana 7586. DRAWN BY JUDI STONE. 
Table 1. Comparison of Cynorkis elephantina, C. mammuthus and C. kiehnii.

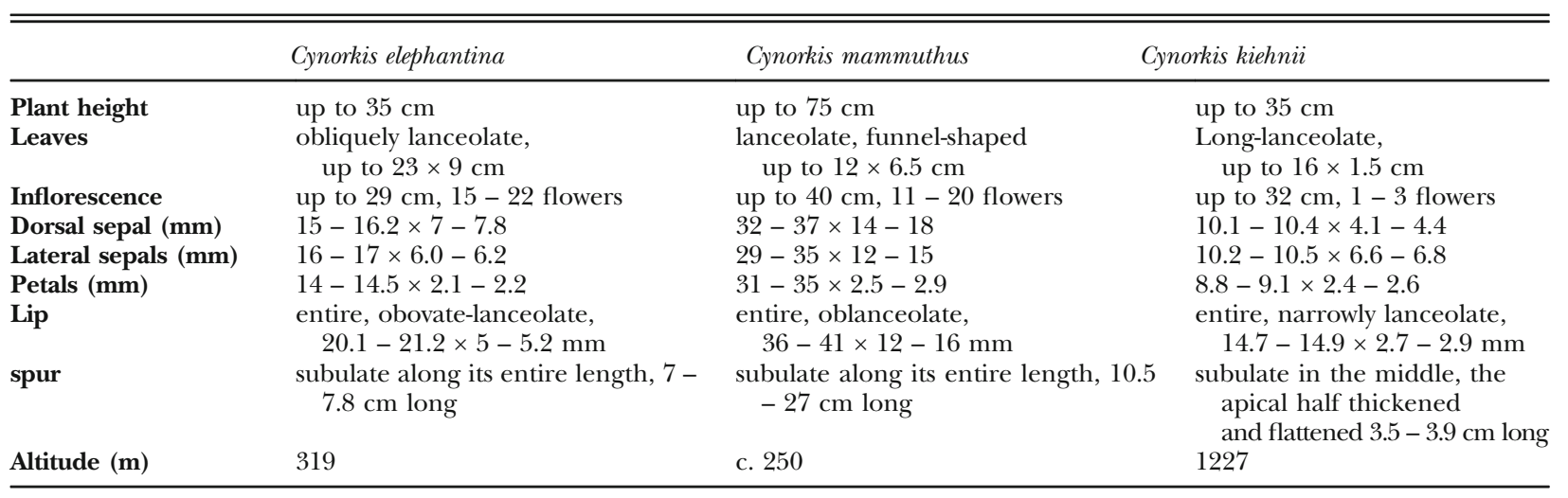

becoming darker within the throat and a brownish red spur, a white column with the margins purple, and a green ovary with purple-red grooves. Pedicel with ovary fusiform, slightly arched, glabrous except for the join with the base of the column which has a few scattered glandular hairs, $21-23 \times 12.1 \mathrm{~mm}$. Dorsal sepal ovate, $8.2-8.5 \times 3.5-3.6 \mathrm{~mm}$, forming a hood over the column with the petals obtuse, with glandular hairs on the exterior. Lateral sepals spreading, oval-lanceolate, $9.9-10.2 \times 4.6-5.1 \mathrm{~mm}$, obtuse, with a few hairs at the base. Petals narrowly lanceolate, falcate, $8.2-8.4 \times$ 1.9 - 2 mm. Lip unequally 4-lobed, $21-23 \times 11-13$ $\mathrm{mm}$; lateral lobes elliptic, rounded; mid-lobe dividing around the middle into two oblanceolate, obtuse lobes, the margins a little reflexed; the disc raised a little in the centre forming a rounded ridge; spur slightly sigmoid, parallel with the ovary, $22-23 \times 0.9-$ $1.1 \mathrm{~mm}$, gradually narrowing towards the apex, the base with a few glandular hairs. Column horizontal, overall c. $5 \times 3 \mathrm{~mm}$, with two $2 \mathrm{~mm}$ attenuate rostellum arms for $1 / 3$ its length, with a narrow nose-like mid-lobe recurved at the apex, anther loculi ovoid. Pollinia with $1.5 \mathrm{~mm}$ long caudicles. Figs 3, 4 .

RECOGNITION. Cynorkis marianneae is recognised by its long ligulate leaf, few-flowered inflorescence, and flowers with a four-lobed lip with the elliptic lateral lobes with rounded margins, a mid-lobe divided into two oblanceolate, obtuse lobes with the margins a little reflexed, a spur about the same length as the ovary and the column with a narrow, recurved mid-lobe.

There are strong similarities with both Cynorkis flexuosa Lindl. (Lindley 1835: 331) (Fig. 5A) and C. speciosa Ridl. (Ridley 1886: 122) (Fig. 5B): it is likely that it is a natural hybrid of these two common and variable species. All three were found flowering in the same locality, a few paces apart, with $C$. flexuosa the most common. Table 2 shows a comparison of the three species, measurements for $C$. flexuosa and C. speciosa are based on averages of 42 specimens from various herbaria and descriptions. Cynorkis marianneae, is similar in general plant habit and size to both species, it shares the overall lip and spur shape with both but has an intermediate petal, lip and spur size between the two. Both putative parents are very variable in colour but they share the green dorsal sepal-petal hood; the lip of C. speciosa is normally palepink to white with an undefined darker pink area at its base, C. flexuosa invariably has a yellow lip with generally a defined dark red-maroon spot at its base, it is therefore possible that the colour of $C$. marianneae is a combination of these.

Cynorkis marianneae differs from C. speciosa by the fewer and smaller flowers, the smaller petals, lip and slightly shorter spur. The lobes of the lip do not overlap and the lateral lobes are rounded vs angular sinuate, the anterior lobes are obtuse (vs angular) and slightly repand (vs undulate). The column structure is also different, with a narrow recurved mid-lobe of the rostellum (vs a broader truncate one in C. speciosa). It differs from $C$. flexuosa by its slightly larger flowers with especially the lip and petals over the maximum recorded size of C. flexuosa, it also lacks the yellow colour of the lip which is consistent in C. flexuosa. The spur is sigmoid (vs straight) and over a third longer. The rostellum arms are less deeply divided and the narrow recurved mid-lobe is intermediate between C. flexuosa and C. speciosa.

All the described varieties of Cynorkis flexuosa and C. speciosa were compared but none matched the new entity.

DISTRIBUTION. Endemic to the Highlands of Madagascar, in Antananarivo province.

SPECIMENS EXAMINED. MADAGASCAR. Antananarivo prov. Ankazobe area, along RN4, Jan. 1996, in grass verge, in shade beneath scrub in a pine copse, Hermans 8135 (holotype K!). 

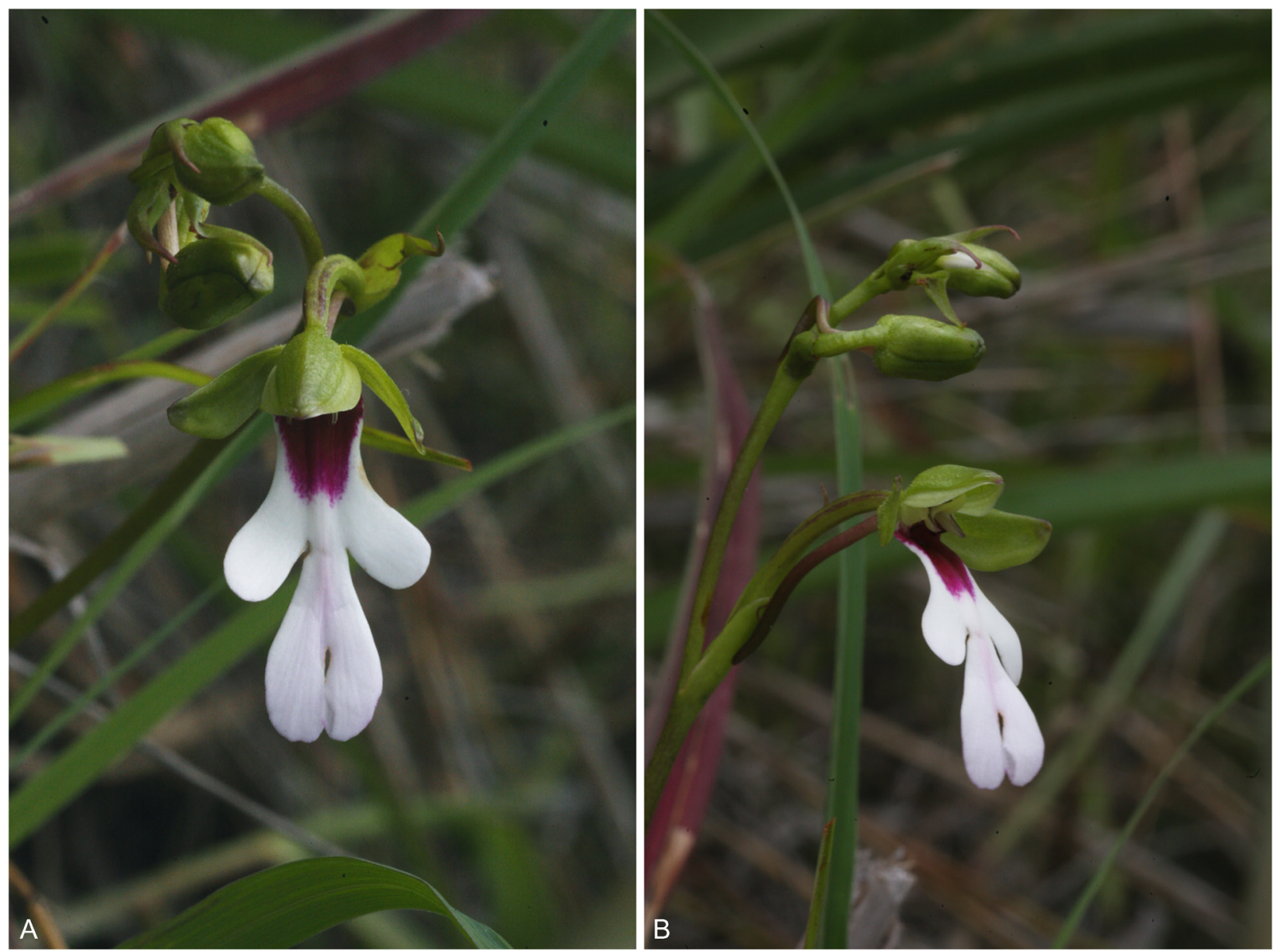

Fig. 3. Cynorkis marianneae. A flower, face view; B flower, lateral view. PHOTOS: JOHAN HERMANS.

HABITAT. Seasonally dry grassland, in shade of pine trees.

CONSERVATION STATUS. Cynorkis marianneae is only known from a single unprotected locality in Analamanga region, Antananarivo province. The species is assessed as Critically Endangered CR based on Criterion $\mathrm{D}$, with the number of mature individuals is likely to be fewer than 50 (only a single plant was observed in the type locality), and under criterion $\mathrm{B} 2 \mathrm{ab}(\mathrm{i}, \mathrm{ii}, \mathrm{iii})$ with a continuing decline in the value of the AOO and the EOO estimated to be less than $10 \mathrm{~km}^{2}$ and the habitat quality due to human activities such as land clearing and fire for agricultural use.

FLOWERING TIME. January.

ETYMOLOGY. Named for Marianne Cribb who discovered a plant of this species in a secluded position.

NOTES. Natural hybrids in the genus Cynorkis have been recorded a number of times and two include C. speciosa as a parent: C. xsyringescens Hermans \& P.J.Cribb (Hermans et al. 2017: 21) (C. speciosa $\times$ C. fastigiata Thouars (1822: t. 3)) and $C$. xranaivosonii Hermans \& Rajaovelona (2019: 547) (C. speciosa $\times$ C. uniflora Lindl. (Lindley 1835: 331)). Other putative crossings in the genus include $C$. xmirabile Hermans \& P.J.Cribb (2007: 252) ((C. lowiana Rchb.f. (Reichenbach f. 1888: 150) × C. gibbosa Ridl. (Ridley 1883: 331)) and C. paradoxa (Frapp. ex Cordem.) Schltr. (Schlechter 1915: 401) ((C. lilacina Ridl. (Ridley 1885: 515) $\times$ C. ridleyi T.Durand \& Schinz, (1895: 92)). There is no absolute certainty that C. marianneae is a natural hybrid. Further study of populations and other occurrences could confirm its status but meanwhile it is prudent to treat it as a species with similarities to C. flexuosa and C. speciosa.

Cynorkis marmorata Hermans sp. nov. Type: Madagascar, Antananarivo prov., Anjozorobe area, degraded humid evergreen forest, in undergrowth, in shade of small trees, 1305 m, May 1998, Hermans 8257 (holotype K!).

http:/ /www.ipni.org/urn:lsid:ipni.org:names:77211718-1

Small single-leafed terrestrial herb up to $6 \mathrm{~cm}$ tall without the inflorescence. Tubers $1-2$, clustered, ovoid, woolly on the exterior; roots villous, wiry, c. 

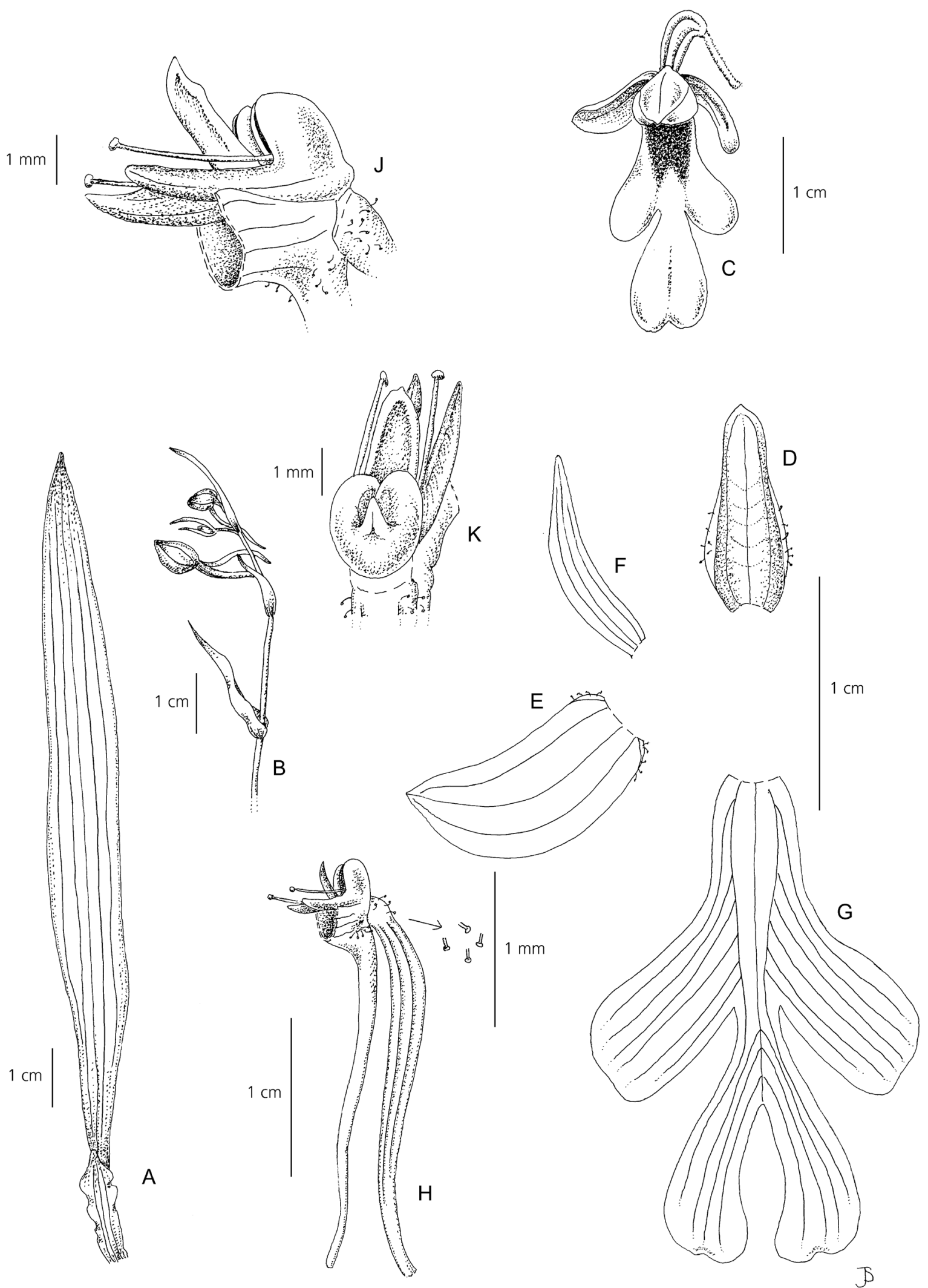

Fig. 4. Cynorkis marianneae. A leaf; B inflorescence; C flower; D dorsal sepal; E lateral sepal; F petal; $\mathrm{G}$ lip; $\mathrm{H}$ column, ovary and lip spur (lip removed); J column, side view; K column from above. From Hermans 8135. DRAWN BY JUDI STONE. 

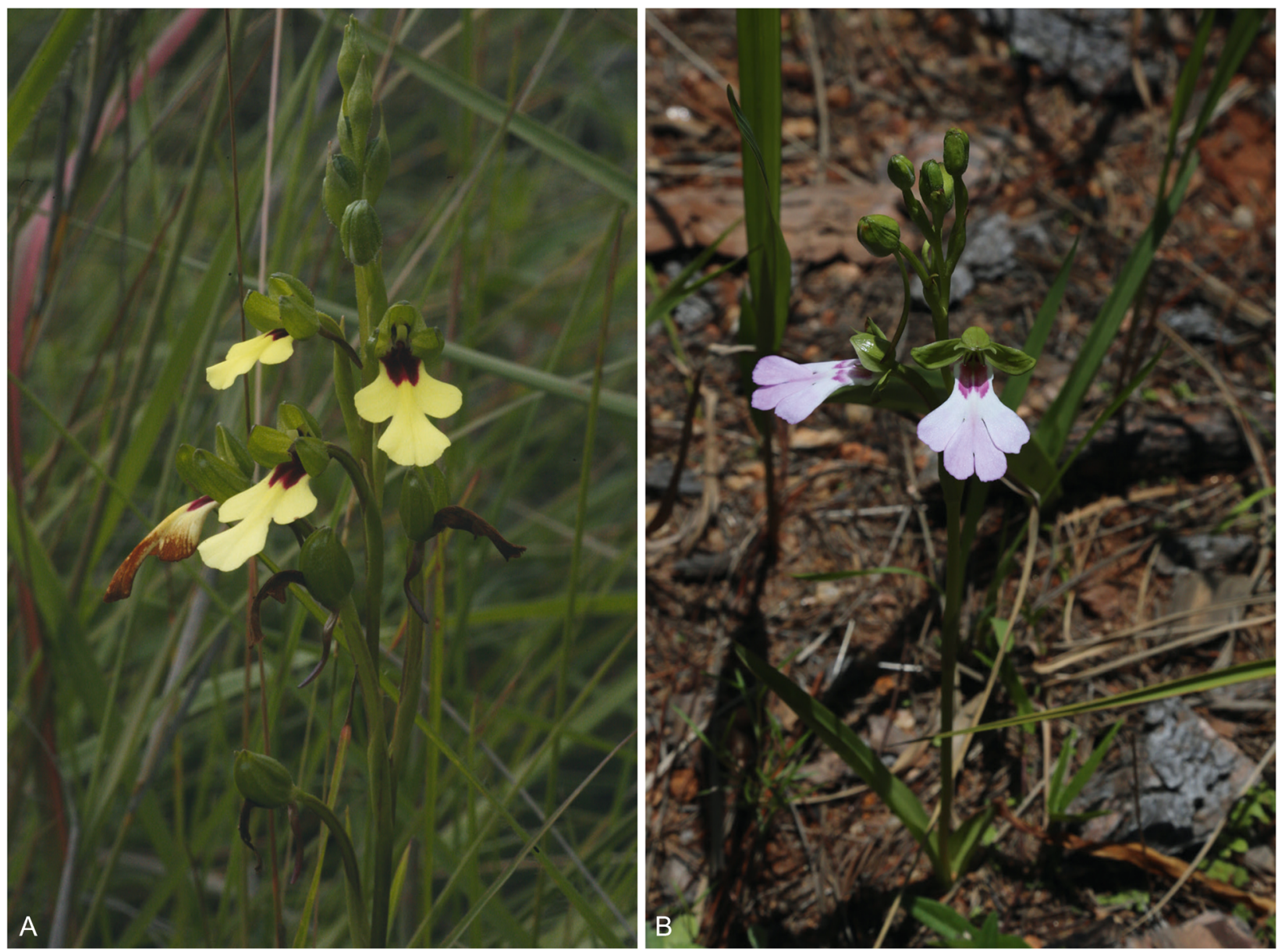

Fig. 5. A Cynorkis flexuosa, plant in habitat, and B C. speciosa, part of inflorescence, for comparison with C. marianneae. PHOTOs: JOHAN HERMANS.

$1 \mathrm{~mm}$ in diam. Leaf on a short, $4-7 \mathrm{~mm}$, stem-like petiole, blade lanceolate, attenuate, $28-53 \times 10-12$ $\mathrm{mm}$, serrate at the margins, pale green with characteristic interrupted, silvery-white horizontal to transversal bands in between the veins, giving it a marbled appearance, brownish-green underneath. Inflorescence erect, slender, up to $25 \mathrm{~cm}$ long. Peduncle angular, hirsute, brownish-green, $1-1.2 \mathrm{~mm}$ in diam., with 1 - 2 lanceolate sheaths, the tip acuminate and the mid-vein thickened, $3.5-3.9 \times 1 \mathrm{~mm}$. Rachis loosely racemose, around half the length of the inflorescence, hirsute, reddish-brown, developing fruits

Table 2. Comparison of Cynorkis flexuosa, C. speciosa and C. marianneae.

\begin{tabular}{|c|c|c|c|}
\hline \multicolumn{2}{|c|}{ Cynorkis flexuosa } & \multirow{2}{*}{$\frac{\text { Cynorkis speciosa }}{17 \times 1.5}$} & \multirow{2}{*}{$\frac{\text { Cynorkis marianneae }}{14 \times 1.2}$} \\
\hline Leaves, average size $(\mathrm{cm})$ & $15 \times 1$ & & \\
\hline Inflorescence average length $(\mathrm{cm})$ & 25 & 30 & 14 \\
\hline Dorsal sepal (mm) & $12-20 \times 2-3$ & $9-12 \times 4-5.3$ & $8.2-8.5 \times 3.5-3.6$ \\
\hline Lateral sepals (mm) & $8-11 \times 4-4.5$ & $9-18 \times 4-6$ & $9.9-10.2 \times 4.6-5.1$ \\
\hline Petals (mm) & $6.5-8 \times 1.5-2$ & $10-12 \times 2.5 \times 3.5$ & $8.2-8.4 \times 1.9-2$ \\
\hline Lip & $\begin{array}{l}16-21 \times 8-15 \mathrm{~mm} \text {, } \\
\text { lobes not overlapping. } \\
\text { Yellow }\end{array}$ & $\begin{array}{l}23-28 \times 14-19 \mathrm{~mm} \text {, } \\
\text { lobes partly overlapping. } \\
\text { Pinkish-white }\end{array}$ & $\begin{array}{l}21-23 \times 11-13 \mathrm{~mm} \text {, } \\
\text { lobes not overlapping. White } \\
\text { tinted pink }\end{array}$ \\
\hline Spur & $\begin{array}{l}8-14 \times 1.5-2 \mathrm{~mm}, \\
\text { straight }\end{array}$ & $20-30 \times 2 \mathrm{~mm}$, sigmoid & $\begin{array}{l}22-23 \times .09-1.1 \mathrm{~mm} \text {, slightly } \\
\text { sigmoid }\end{array}$ \\
\hline Column & $\begin{array}{l}\text { c. } 4 \times 3.5 \mathrm{~mm} \text {, mid-lobe } \\
\text { nose-like, slightly recurved }\end{array}$ & $\begin{array}{l}\text { c. } 6 \times 4 \mathrm{~mm} \text {, mid-lobe broad, } \\
\text { arching }\end{array}$ & $\begin{array}{l}\text { c. } 5 \times 3 \mathrm{~mm} \text {, mid-lobe narrow, } \\
\text { recurved }\end{array}$ \\
\hline
\end{tabular}


whilst the apical flowers are still developing. Floral bracts lanceolate, acuminate, $2.4-2.6 \times$ c. $1 \mathrm{~mm}$, brownish-green. Flowers c. $10 \times 8 \mathrm{~mm}$, non-resupinate, divaricate, white to pale pink with pale brownish-green sepals and spur, and a lip with the disc with $3-4$ longitudinal reddish-brown bands, a small pink patch on the mentum underneath, continuing along the mid-vein. Pedicel with ovary fusiform, straight, $8.1-8.7 \times 1.2-1.4 \mathrm{~mm}$, very hirsute, some of the hairs glandular. Dorsal sepal forming a loose hood with the petals, broadly ovate, $2.3-2.4 \times 2.2-2.4 \mathrm{~mm}$, obtuse, glandular on the exterior. Lateral sepals spreading, lanceolate-falcate, $3.5-3.7 \times 2.2-2.3 \mathrm{~mm}$, attenuate, glandular on the exterior. Petals lanceolate, acute, $2.5-2.7 \times 0.8-0.9$ mm. Lip 3-lobed with a short concave hypochile towards the base, $3.9-4.2 \times 4-4.2 \mathrm{~mm}$, the lateral lobes triangular, attenuate, the midlobe broadly ovate, with undulate margins, glabrous except for the exterior of the hypochile which has a few hairs; spur curved, $3.3-3.5 \times 0.7-0.8 \mathrm{~mm}$, broadened at the base, then tubular, then clavate at the tip. Column in a flat blade, c. $1.3 \times 1.2 \mathrm{~mm}$, the rostellum angular and entire for almost its whole length; anther loculi ovoid. Pollinia c. $1.2 \mathrm{~mm}$, with a long caudicle. Fruit fusiform, purple, c. $9 \times 3 \mathrm{~mm}$. Figs 6,7 .

RECOGNITION. With its small flowers with the lip uppermost and column characteristics Cynorkis marmorata belongs in sect. Hemiperis (Frapp. in Cordem.) Perrier in Humbert (1939: 74). It is recognised by its small lanceolate leaf with serrate margins and the silvery reticulate markings on the blade, its long hirsute inflorescence, and small hairy flowers with an unequally 3-lobed lip with a rounded hypochile at the base, and an upturned spur clearly clavate at the tip.

Cynorkis marmorata is somewhat similar to C. henrici Schltr. (Schlechter 1924: 52), C. ridleyi T.Durand \& Schinz (1895: 92) and C. sororia Schltr. (Schlechter 1913: 154) with which it shares the general lip shape, short thin spur and patterned leaves but they all have much larger flowers and bigger ovate leaves. It is closest to C. flabellifera H.Perrier (1951: 144) with which it shares a similar general habit, lip and spur shape but it consistently has a narrower leaf with an up to $7 \mathrm{~mm}$ petiole (vs $45 \mathrm{~mm}$ ), and flowers that are about $1 / 3$ its size, a dorsal sepal that is broadly ovate (vs lanceolate), a lip with an ovate mid-lobe (vs flabellate), C. flabellifera also lacks the serrate leaf margins and has purple-white flowers and has only been found in Antsiranana province in the far north of Madagascar.

DISTRIBUTION. Endemic to Antananarivo province of Madagascar.
SPECIMENS EXAMINED. MADAGASCAR. Antananarivo prov., Anjozorobe area, May 1998, 1305 m, Hermans 8257 (holotype K!).

HABITAT. In humid evergreen forest, in deep shade, in small scattered clumps, amongst leaf humus, mosses and lichens. c. $1300 \mathrm{~m}$.

CONSERVATION STATUS. Cynorkis marmorata is only known from a single unprotected locality in the Analamanga region, Antananarivo province. The species is assessed as Critically Endangered CR based on Criterion D, with the number of mature individuals likely to be fewer than 50 (around 25 plants were seen in one locality), and under criterion B2ab(i,ii,iii) with a continuing decline in the value of the AOO and the EOO estimated to be less than $10 \mathrm{~km} 2$ and the habitat quality due to human activities such as shifting agriculture and forest logging.

FLOWERING TIME. April to May.

ETYMOLOGY. Referring to its marbled leaf.

Cynorkis murex Hermans sp. nov. Type: Madagascar, Toamasina prov., near Andasibe, c. 1150 m, May 1996, Hermans 8240 (holotype K!).

http://www.ipni.org/urn:lsid:ipni.org:names:77211719-1

Erect terrestrial herb up to $15 \mathrm{~cm}$ high excluding the inflorescence. Tubers $2-3$, elongate, ovoid, $2-3 \times 0.5$ $-1 \mathrm{~cm}$, clustered, surface velvety; roots villous, fleshy, wiry c. $1.5 \mathrm{~mm}$ in diam. Stem short, $1-2 \mathrm{~cm}$ long. Leaf solitary, broadly lanceolate, caudate at the apex, $52-$ $75 \times 23-31 \mathrm{~mm}$, attenuate at the apex, with five prominent veins, margins undulate, pale green with the veins a little darker, the mid-vein bordered by a broader dark area, on a long $30-52 \times 3-7 \mathrm{~mm}$ petiole enveloped for a third of its length by a sheath. Inflorescence up to $30 \mathrm{~cm}$ long, $1.5-2 \mathrm{~mm}$ in diam., finely pubescent. Peduncle with $4-6$ equally spaced sheaths $6-8 \times 1.4-1.6 \mathrm{~mm}$. Rachis racemose, c. $5 \mathrm{~cm}$ long, loosely 12 - 17-flowered. Floral bracts lanceolate, acuminate, irregularly spinose at the margins and along the mid-vein, bright purple when young, becoming reddish-brown with age. Flowers porrect, spreading, c. $10 \times 15 \mathrm{~mm}$, pale pinkish-white with much darker purple-magenta markings, a pale pinkish-white dorsal sepal, lateral sepals with parallel dark purple-magenta bands, sometimes fused into one, petals with purple margins, a lip with small purple spots at the base and several triangular spots alongside the paler central vein, a spur with a darker purple tip, rostellum arms edged purple, and purplishred anther loculi. Pedicel with ovary fusiform, $13-14.5$ $\times 1.8-1.9 \mathrm{~mm}$, hirsute, white. Dorsal sepal ovate, 4.1 $4.3 \times 1.9-2 \mathrm{~mm}$ forming an arching hood over the column with the petals, the apical part narrowed, the 

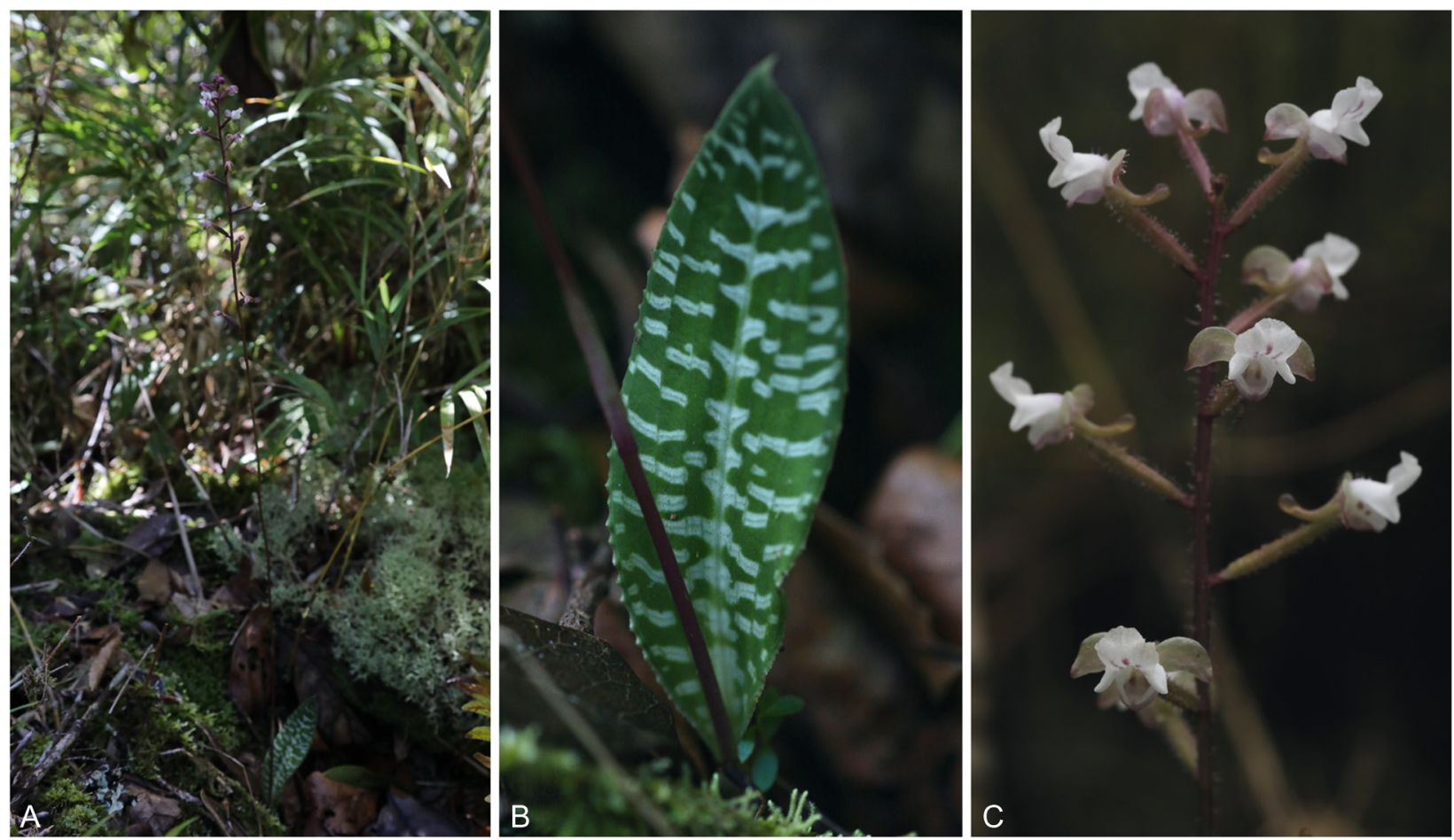

Fig. 6. Cynorkis marmorata. A plant in habitat; B leaf; C rachis. PHOTOS: JOHAN HERMANS.

exterior longly and densely hirsute. Lateral sepals spreading, parallel with the lip, ovate-acute, $5.8-6 \times$ 3.1 - $3.2 \mathrm{~mm}$, margins incurved, hirsute on the exterior. Petals partly covered by the dorsal hood, oblong-lanceolate, $3.2-3.3 \times 1.1-1.2 \mathrm{~mm}$, the apex with a small auricle, glabrous. Lip 5-lobed, $6.3-6.5 \times$ $4.9-5 \mathrm{~mm}$, the basal lobes small, rounded deltate, the lateral lobes strongly attenuate-angular, incurved, the mid-lobe strongly attenuate-angular recurved at the tip, the disk with a longitudinal raised ridge along its length; spur $8.9-9.1 \times 2.1-2.3 \mathrm{~mm}$, in the basal $2 / 3$ parallel to the ovary, narrowing, hirsute, then abruptly narrowed, descending and glabrous. Column angular $3.2-3.3 \times 2.4-2.5 \mathrm{~mm}$, with two $3 \mathrm{~mm}$ rostellum arms for over half its length, with a small nose-like midlobe, unevenly obovoid-auricular staminodes towards the base, anther loculi elongate. Pollinia finely granular, c. $3.2 \mathrm{~mm}$ long including the long caudicle. Figs 8, 9.

RECOGNITION. Cynorkis murex is recognised by its single broadly lanceolate leaf on a petiole almost as long as the blade, its tall loosely racemose inflorescence, and hirsute, brightly coloured flowers with a 5-lobed lip and a descending, angular spur.

Its closest relative is undoubtedly Cynorkis densserpens Hermans \& P.J.Cribb (2014: 1) (Fig. 10), described recently from the same area: it shares the plant habit, some of the floral characteristics, and it also flowers at the same time. The new species is very different in that the leaf margins are undulate and entire (vs serrate). The lip is consistently smaller and has rounded-deltate (vs auriculate) basal lobes, strongly attenuate-angular lateral lobes and mid-lobe (vs rounded-obtuse), an angular, descending spur (vs ascending, subulate), it is also a little shorter, $3 \mathrm{~mm}$ long rostellum arms (vs $2 \mathrm{~mm}$ ) and staminodes that are a different shape (they are compared in Table 3). The colour of the flowers is also consistently and considerably different.

DISTRIBUTION. Endemic to the Andasibe area in Toamasina province in Eastern Madagascar.

SPECIMENS EXAMINED. MADAGASCAR. Toamasina prov., near Andasibe, c. 1150 m, May 1996, Hermans 8240 (holotype K!).

HABITAT. In humid evergreen forest, on wooded banks near small streams, in moist humus, in dappled shade. c. $1150 \mathrm{~m}$.

CONSERVATION STATUS. Cynorkis murex is endemic to Madagascar and distributed in Alaotra-Mangoro region in Toamasina province. The value of the area of occupancy (AOO) is estimated to be less than $10 \mathrm{~km}^{2}$. The species is located outside protected areas. In addition, the EOO, the AOO and the habitat of the species are suffering a continuing decline due to shifting agriculture. It is therefore assessed as Endangered (EN). Further research is recommended, particularly on population size of this species.

FLOWERING TIME. May.

ETYMOLOGY. Referring to Murex, a genus of molluscs, often with a prickly exterior, once used to produce the 


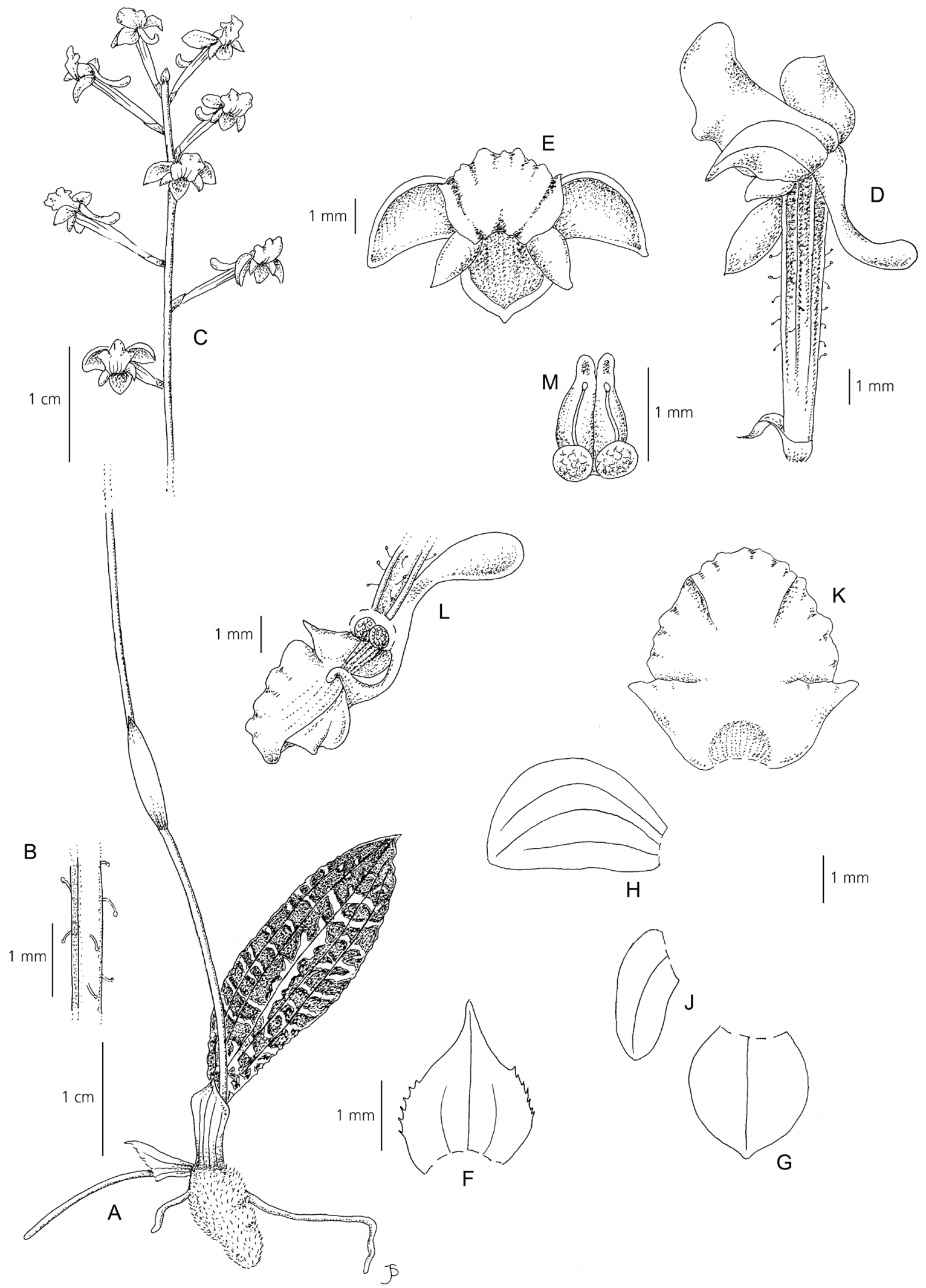

Fig. 7. Cynorkis marmorata. A base of habit; B part of stem, enlarged; $C$ inflorescence; $D$ flower side view; $E$ flower, front view; $F$ floral bract; G dorsal sepal; H lateral sepal; J petal; K lip; L column and lip, side view; M column. From Hermans 8257 . DRAWN BY JUDI STONE. 

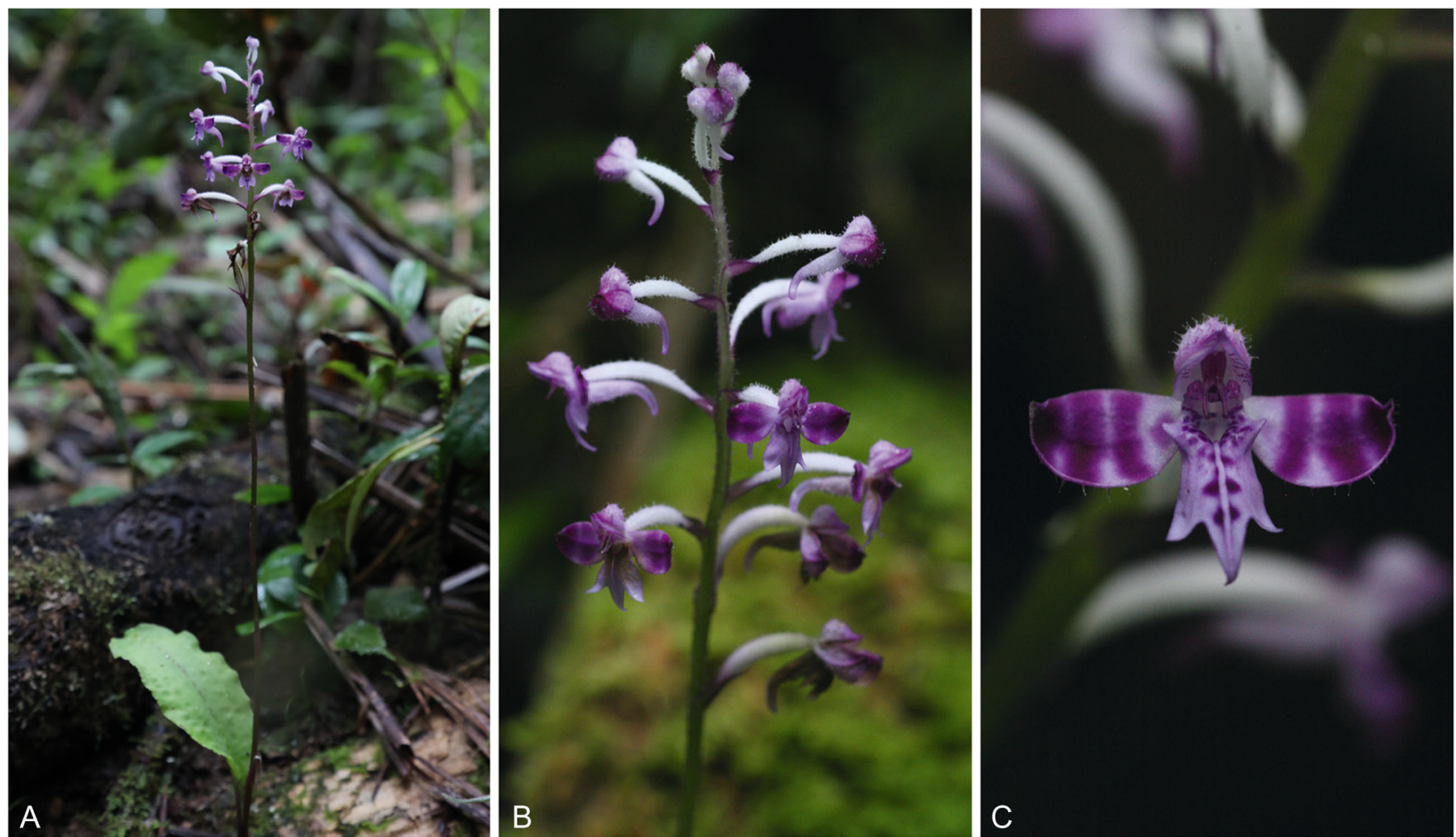

Fig. 8. Cynorkis murex. A plant in habitat; B rachis; C flower, face view. PHOTOS: JOHAN HERMANS.

Tyrian purple dye, similar in colour to the markings on the flower of the orchid.

NOTES. Cynorkis dens-serpens and C. murex are known from several substantial colonies, about $10 \mathrm{~km}$ apart in separate valleys: all plants within each of these colonies were consistent in shape, size and colour and no intermediate forms have been found.

\section{The identity of Cynorkis frappieri and C. raymondiana}

Cynorkis frappieri Schltr. (Schlechter 1915: 400) as Cynosorchis frappieri; Bernet (2010: 150); Szelengowicz \& Tamon (2013: 269). Type: Réunion, 'Tampon, rive gauche du bras de Jean Payet' (Frappier 1895: 237), probably not preserved. Neotype designated here: île de Bourbon [Réunion], Herbier A. Delteil s.n. (Herb. Drake) (neotype P00693021!).

Hemiperis tenella Frapp. ex Cordem. (Frappier 1895:

237); Frappier nom. nud. (1880: 11). Type as above.

Cynorkis raymondiana H.Perrier ex Hermans (Hermans et al. 2007: 292); Cribb \& Hermans (2009: 80) synon. nov. Lectotype: Madagascar, nr FortDauphin [Tôlanaro], Decary 10142 (lectotype P00102022!), designated here. Paratype: Decary 10019 (P00102023!).

Cynosorchis raymondiana H.Perrier in Arch. Bot. Bull. Mens. 5 (1931: 48) (unpublished, see Hermans 2007: 290): Perrier (1939: 97).

Bicornella raymondiana (H.Perrier.) Szlach. \& Kras (Szlachetko \& Kras 2006: 145), nom. invalid.
Small squat herb up to $7 \mathrm{~cm}$ high excluding the inflorescence. Tubers $1-2$, clustered, ovoid, $1-2 \times$ $1.3-1.8 \mathrm{~mm}$, woolly on the exterior; roots villous, wiry, c. $1 \mathrm{~mm}$ in diam. Leaves $2-3$, flat, radical, ovate to lanceolate, $3.7-8.2 \times 1-2.8 \mathrm{~cm}$, with a very short conduplicate petiole attenuate at the tip, margins entire, green. Inflorescence erect, racemose, up to $22 \mathrm{~cm}$ long, glabrous, green with up to 13 flowers but generally fewer. Peduncle slender, $1.5-2 \mathrm{~mm}$ in diam., over $2 / 3$ the length of the inflorescence, with $3-$ 5 distant lanceolate peduncle sheaths, $5-12 \times 1.1-$ $2.2 \mathrm{~mm}$, the basal one longer and more acuminate than the others. Rachis laxly flowered, $2-6 \mathrm{~cm}$. Floral bracts lanceolate, acuminate, $3.8-4.9 \times 1.3-1.5 \mathrm{~mm}$. Flowers very small for the genus, erect to arching, up to $7 \times 6 \mathrm{~mm}$, glabrous, crystalline white with the exterior of the sepals more or less tinted pinkish green, the lip with up to 6 , more or less merging, magenta spots, with magenta-marked basal lobes, and yellow pollinia, (Szelengowicz \& Tamon (2013: 270) report forms without distinct spots on the flowers and other forms with an overall pink to mauve pigmentation). Said to be scented of goat (d'odeur hircine) by Frappier (1895: 238) but this has not been verified in the field. Pedicel with ovary fusiform, $6-10 \times 1-1.2$ $\mathrm{mm}$, glabrous, green. Dorsal sepal forming a tight hood with the petals, broadly ovate, obtuse, concave, $2.1-3 \times 1.5-1.8 \mathrm{~mm}$. Lateral sepals spreading, ovate, concave, $2.8-3.0 \times 1.5-1.8 \mathrm{~mm}$. Petals lanceolate to elliptic, acute, $2-2.5 \times 0.9-1.2 \mathrm{~mm}$. Lip obcordate, unequally 5-lobed, $3.2-4 \times 2.5-2.9$ 


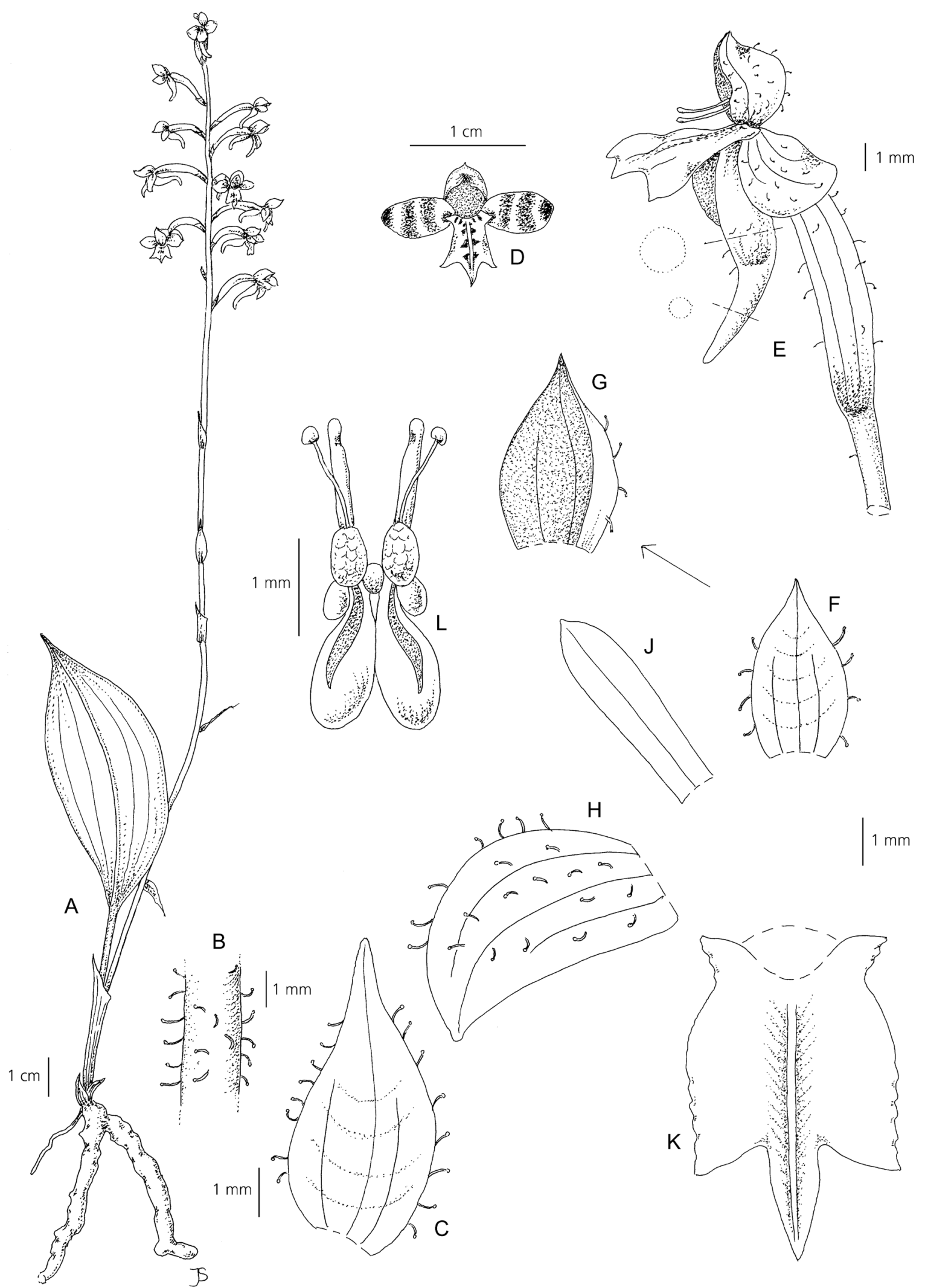

Fig. 9. Cynorkis murex. A habit; B stem, enlarged view; C floral bract; D flower front view; E flower, side view; F dorsal sepal, front view; G dorsal sepal, oblique view; H lateral sepal; J petal; K lip; L column from above. From Hermans 8240. DRAWN BY JUDI STONE. 

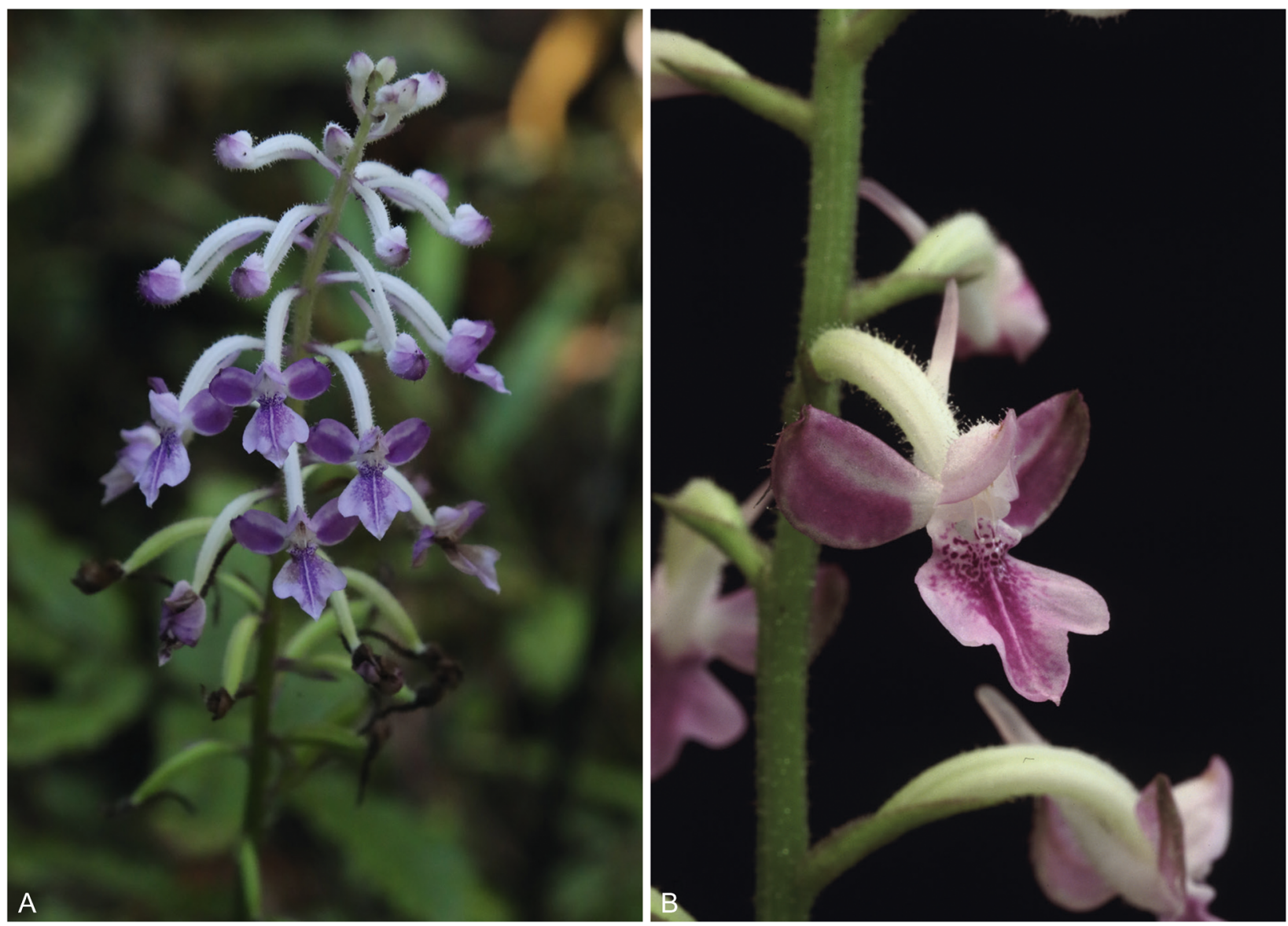

Fig. 10. Cynorkis dens-serpens. A rachis, B close up of flower, for comparison with C. murex. PHOTOS: JOHAN HERMANS.

$\mathrm{mm}$, the anterior lobe triangular acute, the lateral lobes a little larger, obovate obtuse, the basal lobes small, triangular acute; spur thickened in the lower half to club-shaped, $1.5-1.8 \times 0.4-0.6 \mathrm{~mm}$. Column in a horizontal blade to somewhat ascending, $1-1.7 \times 1-$ $1.1 \mathrm{~mm}$, anther bilobed, midlobe of the rostellum and staminodes small, rounded, lateral lobes of the rostellum bidentate at the front, with the midlobe of the rostellum appearing tridentate, the pollinia ending in a distinct viscidium. Figs 11, 12.
RECOGNITION. With its slender plant habit, laxly fewflowered inflorescence, small flowers and rostellum with a short toothed horizontal blade Cynorkis frappieri belongs in sect. Hemiperis (Frapp. ex Cordem.) Perrier in Arch. Bot. Bull. Mens. 5 (1931: 36 unpublished); Perrier (1939: 74). It is recognised by its glabrous habit and flowers, two or rarely three ovate to lanceolate leaves flattened on the ground, a long peduncle at least $2 / 3$ the length of the inflorescence, and small white with distinct magenta spotted flowers with a

Table 3. Comparison of Cynorkis dens-serpens and C. murex.

\begin{tabular}{lll}
\hline \hline & \multicolumn{1}{c}{ Cynorkis dens-serpens } & \multicolumn{1}{c}{ Cynorkis murex } \\
\hline Inflorescence & up to $25 \mathrm{~cm}$ tall, $8-15$ flowers & up to $30 \mathrm{~cm}$ tall, $12-17 \mathrm{flowers}$ \\
Dorsal sepal $(\mathbf{m m})$ & $3.8-5 \times 2-3$ & $4.1-4.3 \times 1.9-2$ \\
Lateral sepals $(\mathbf{m m})$ & $5.7-6 \times 3.9-4.5$ & $5.8-6 \times 3.1-3.2$ \\
Petals $(\mathbf{m m})$ & $3.6-4.3 \times 1.5 \times 2$ & $3.2-3.3 \times 1.1-1.2$ \\
Lip & 5 -lobed, basal lobes auriculate, lateral \& & 5 -lobed, basal lobes rounded deltate, \\
& mid-lobes rounded-obtuse, $7-10 \times 7-9 \mathrm{~mm}$ & lateral \& mid-lobes strongly \\
& & attenuate-angular, $6.3-6.5 \times 4.9-5$ mm \\
Spur & ascending, subulate, straight, up to $12 \mathrm{~mm}$ long & angular descending, narrowing, up to 9 mm \\
Column & rostellum arms c. 2 mm, staminodes globose & rostellum arms c. 3 mm, staminodes obovoid, auricular
\end{tabular}



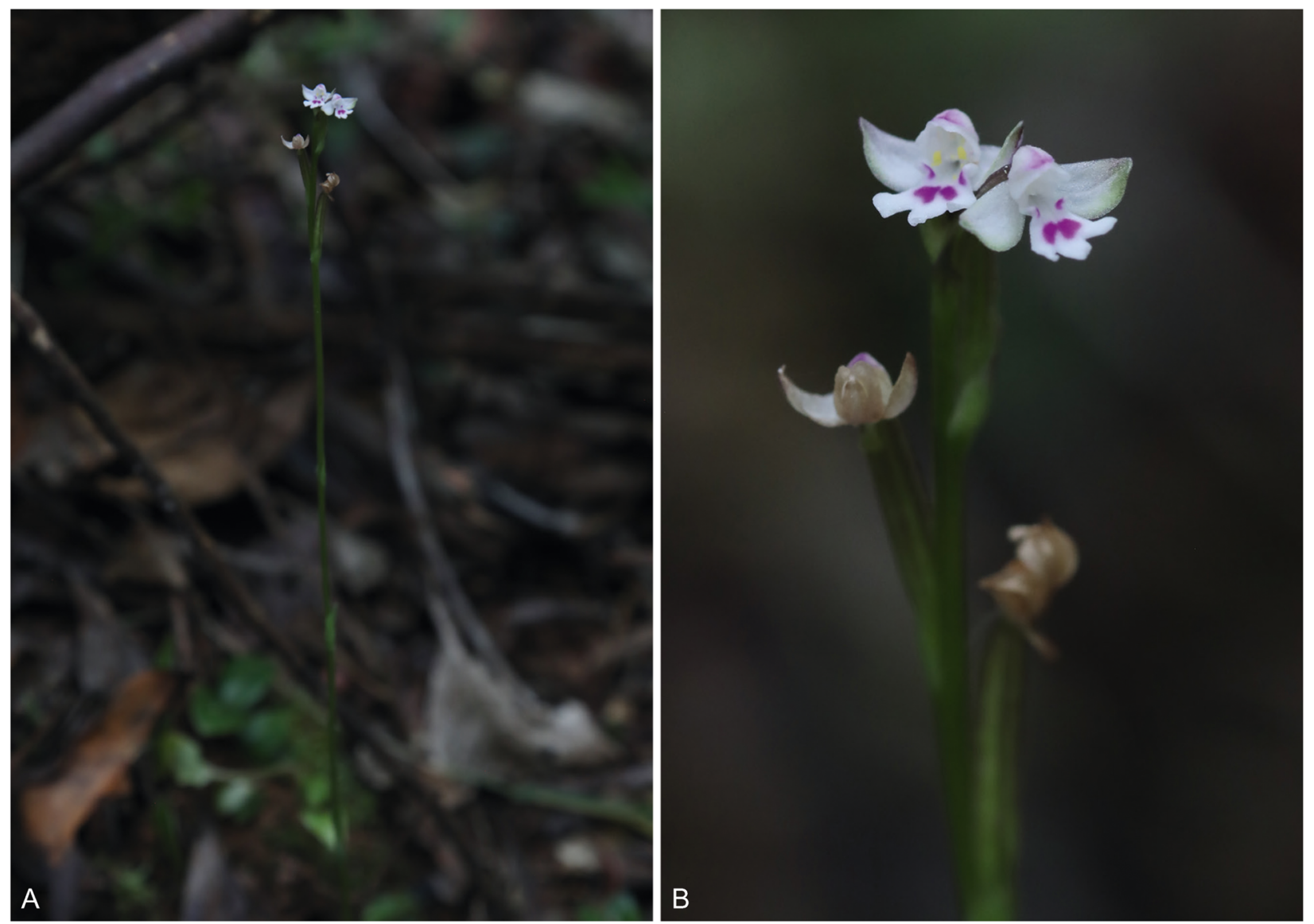

Fig. 11. Cynorkis frappieri. A plant in habitat; B part of inflorescence. PHOTOS: JOHAN HERMANS.

short spur swollen in the lower half. In habit and flower shape it is similar to C. sigmoidea (K.Schum.) Kraenzl. (Kraenzlin 1898: 490) from the Comoros but the flowers of that species are almost double the size, the lip segments narrower and the raceme and ovary pubescent (vs glabrous). It is also similar to C. tenella Ridl. (Ridley 1886: 124) from Madagascar and the Comoros but the flowers of that species are a third larger, the spur double the length and the lip 3-lobed (vs 5-lobed), the raceme, ovary and back of the dorsal sepals are pubescent (vs glabrous). Examination of all the herbarium specimens of $C$. frappieri and C. raymondiana combined with field observations confirm that these taxa are identical in all respects with the former name having priority. A drawing and manuscript notes, accompanying the Delteil s.n. (P00693021) herbarium sheet, contain an annotation by Bosser that it is 'similar and may be the same species as Cynorkis raimondiana'.

DISTRIBUTION. Widely distributed on Madagascar from the central area in Antananarivo province, through the NE mountains in Fianarantsoa province to the far south in Toliara province. Also widespread on Réunion ranging from the east, the south-west and Cirque de Cilaos in the centre. Known from one locality in western Mauritius.
SPECIMENS EXAMINED. MADAGASCAR. Fort-Dauphin, littoral forest, 18 July 1932, R. Decary 10142 (P00102022!); nr Fort-Dauphin, littoral forest, $8 \mathrm{Ju}-$ ly 1932, R. Decary 10019 (P00102023!); Ambondrombe area, moss forest remnants, c. 1200 m, 10 April 1941, Herb. Jard. Bot. Tan. 4572 (P00102024!, P00102025!); Antananarivo prov. nr Anjozorobe, Andrianarivo, 1305 m, May 2018, Hermans 8226 (K!). MAURITIUS. Corps de Garde, June 1976, J. Bosser 22267 (P00693026!). RÉUNION. île Bourbon, Herbier A. Delteil s.n. (Herb. Drake) P (P00693021!); Mare Longue, Saint-Philippe, Dec. 1971, Bosser 20848 (P-spirit!); Basse Vallée, Dec. 1972, J. Bosser 21602 (P0069992!).

HABITAT. On Réunion in humid forest, montane forest and drier areas, terrestrial or very rarely epiphytic in semi-shade at an altitude from 400 - 1300 m (Bernet (2010: 150). On Madagascar in humid forest, 'Tapia' forest and littoral forest in semi-shade at an altitude from $0-1305 \mathrm{~m}$.

CONSERVATION STATUS. Cynorkis frappieri has a large distribution in Madagascar in Analamanga, HauteMatsiatra and Anosy regions from Antananarivo, Fianarantsoa and Toliara regions. It is also widespread in Réunion, ranging from East, the SW and Cirque de Cilaos in the centre and known from one locality in 


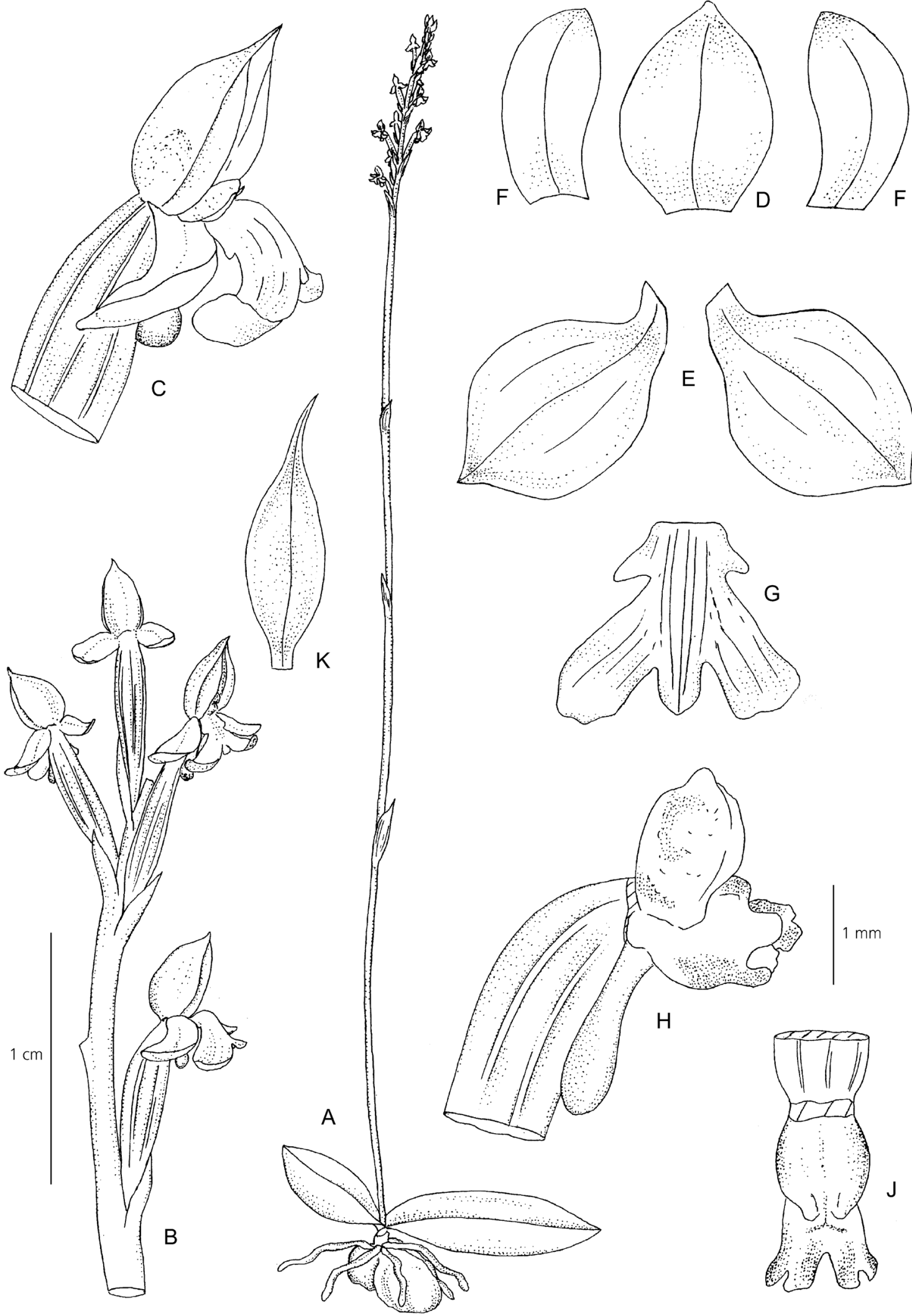

Fig. 12. Cynorkis frappieri. A habit; B tip of inflorescence; C flower, side; D dorsal sepal; E lateral sepals; F petals; G lip; H column and spur, side; J column, top. From Decary 10141. DRAWN BY LINDA GURR after sketches by J. Hermans. 
Mauritius. The extent of occurrence (EOO) is estimated to be more than $20,000 \mathrm{~km}^{2}$. The species is not recorded in any Protected Areas in Madagascar it is therefore inferred that most of its subpopulations are threatened by habitat destruction due to slash and burn agriculture (Tavy) and fires set for land-clearing and pastureland. The species is therefore assessed as Near Threatened (NT).

FLOWERING TIME. Madagascar: May to June. Mauritius: June. Réunion: March to July.

ETYMOLOGY. Tenella: from the Latin tenellus, small and delicate, refers to the small and delicate nature of the plant; raymondiana refers to Raymond Decary (1891 1973), French colonialist and naturalist who collected a large number of plants, described by Perrier; frappieri refers to the French botanist Charles Frappier de Montbenoist (1813-1885).

NOTES. Frappier first listed Hemiperis tenella (1880: 11) from Réunion but this was without description or indication of a type. The first description of Hemiperis tenella was by Frappier in Cordemoy's Flore de l'île de la Réunion (1895: 237) and had an extensive protologue but did not refer to type material, it only mentioned the specific locality of Saint-Pierre (Tampon, rive gauche du bras de Jean Payet) where a plant was seen (vu viv.) by the author. No herbarium material has been found so far of the species directly associated with Frappier or Cordemoy but there is a good specimen at $\mathrm{P}$ originating from A. Delteil s.n. ex herbier Drake (P00693021), which is contemporary with the description and is selected here as the neotype for the species. Schlechter transferred H. tenella, together with many other Hemiperis, to Cynorkis in 1915 but the name C. tenella could not be transferred as it had been used by Ridley in 1886 (p. 124) for a different species from Madagascar and the Comoros. Cynosorchis raymondiana H.Perrier (1931: 48), mentioned by Perrier in the Flore de Madagascar (1939: 97), was never effectively published but later validated, as explained in Hermans et al. (2007: 290). Perrier (1939: 97) cited two Decary specimens (10019 and 10142), collected a few days apart near Fort-Dauphin [Tôlanaro] in southern Madagascar, no holotype was indicated in Perrier's protologue, in the validation of the species in Hermans et al. (2007: 292) Decary 10141 was listed as the Holotype in error. The herbarium sheet Decary 10142 in $\mathrm{P}$ was annotated in Perrier's hand as 's $p$. nov. type', Decary 10019 was annotated 'sp. nov. identical to Decary 10141!'. Under the International Code of Nomenclature for algae, fungi and plants (Turland et al:: 2018: article 9.3 \& 9.11) a lectotype had to be designated: Decary 10142 was chosen here because it was indicated as 'type' by Perrier and the specimen, containing five plants is more complete and representative. Decary 10019 is a paratype. It is interesting to note that Perrier used the spelling 'raimondiana' on the herbarium sheets.
Szlachetko \& Kras (2006: 145) in their unsubstantiated fragmentation of the genus invalidly transferred Cynorkis raymondiana to the genus Bicornella (Lindley 1835: 335) and incorrectly referred to Perrier's basionym as published in Archivio Botanico per la Sistematica, Fitogeografia e Genetica 5: 48 (1931).

\section{The identity of Cynorkis gaesiformis, C. galeata, C. nutans C. stenoglossa}

Cynorkis nutans (Ridl.) H.Perrier (1936: 582); Perrier (1939: 156); Hermans et al. (2007 158); Cribb \& Hermans (2009: 111); Bosser \& Lecoufle (2011: 293); Szelengowicz \& Tamon (2013: 277); Hervouet (2018: 299). Types (former syntypes): Madagascar, Central, Baron 1703 (lectotype BM000032250!; isolectotype K000415611! designated in Hermans et al. (2007: 158); P00102284!); Madagascar, Imerina, Deans Cowan s.n. (paratype BM000911499!); Madagascar, Andrangoloaka, Parker s.n. (paratype K!).

Habenaria nutans Ridl. (Ridley April 1885: 507); Kraenzlin (1901: 923).

Imerinorchis nutans (Ridl.) Szlach. (Szlachetko 2005: 69) synon. nov.

Cynorkis galeata Rchb.f. (Reichenbach f. Oct. 1885: 536) (as Cynosorchis galeata). synon. nov.; Kraenzlin (1901: 923); Perrier (1939: 157); Hermans et al. (2007: 149). Type: Mayotte, Combani forest, Humblot 209 (1209) (holotype W! R5342; isotype P00102270!, P00102271!, P00102272!, BM000034836!).

Imerinorchis galeata (Rchb.f.) Szlach, (Szlachetko 2005: 69) synon. nov.

Cynosorchis nutans var. campenoni H.Perrier (1939: 156), nom. nud.; Hermans et al. (2007: 158). Based upon: Madagascar, Imerina, Nov. 1881, R. P. Campenon s.n. (P00102291!).

Cynorkis stenoglossa Kraenzl. (Kraenzlin 1893: 63); Kraenzlin (1901: 494); Schlechter (1913: 154); Schlechter (1915: 402); Schlechter (1924: 72); Perrier (1939: 158); Hermans et al. (2007: 166); Cribb \& Hermans (2009: 112); Bosser \& Lecoufle (2011: 300). synon. nov. Type: Madagascar, S Betsileo, Ankafina forest, March 1881, J. M. Hildebrandt 4204 (syntype W! R14896).

Imerinorchis stenoglossa (Kraenzl.) Szlach. (Szlachetko 2005: 69). synon. nov.

Cynorkis stenoglossa H.Perrier var. pallens H.Perrier ex Hermans (Hermans et al. 2007: 293); Perrier (1939: 159); Cribb \& Hermans (2009: 112); Hermans et al. (2007: 166); synon. nov. Type: Madagascar, Mt Ambre, H. Perrier 17733 (holotype P00102296!, isotype P102297!).

Cynorkis stenoglossa var. pallens H.Perrier (1931: 72): Perrier (1930: 18). nom. nud.

Cynorkis gaesiformis H.Perrier (1951: 146) synon. nov. Type: Madagascar, S of Moramanga, Decary 18419 (holotype P00102285!). 
Terrestrial, epiphytic or rarely lithophytic herb up to $30 \mathrm{~cm}$ tall including the inflorescence, with $3-6$ elongate pubescent tubers $1-4.5 \times 0.5-1.5 \mathrm{~cm}$; roots dense, woolly. Leaves 1 or rarely 2 , radical, broadly elliptic to oblong, $4.5-19.5 \times 2.5-6.2 \mathrm{~cm}$, tip acuminate, narrowed into a more or less attenuate petiole at the base, blade flat, arching towards the tip, green with the veins often a little paler, with a thin sheath enveloping the base, acuminate to caudate, 1 $3 \mathrm{~cm}$ long. Inflorescence erect to divergent, $6-26 \mathrm{~cm}$ tall, with up to 30 flowers. Peduncle about $2 / 3$ of the inflorescence, $3-4 \mathrm{~mm}$ in diam., densely hirsute along its length, generally with a prominent lower peduncle sheath $12-42 \times 3-19 \mathrm{~mm}$ and $2-3$ additional sheaths $6-12 \times 2.5-3.2 \mathrm{~mm}$. Rachis subdensely to densely racemose, often opening in succession with the lower ones fading before the upper ones open. Floral bracts narrowly lanceolate, $4.8-8.9 \times 1.5-$ $2.1 \mathrm{~mm}$, attenuate, hirsute on the exterior. Flowers variable in size, up to $16 \times 29 \mathrm{~mm}$, very variable in colour, ranging from pale pink to deep mauve-purple, some forms having pink, lilac to purple sepals, lip and petals, the anther loculi brownish-purple. Pedicel with ovary fusiform, $12-24 \times 1.7-3.5 \mathrm{~mm}$, densely hirsute, white to pink. Dorsal sepal lanceolate, $4.5-8.1 \times 2-3.3$ $\mathrm{mm}$, helmet-shaped, the tip recurved, forming a tight hood with the petals, hirsute on the exterior. Lateral sepals broadly lanceolate to ovate, $7.7-17.3 \times 4-7.9$ $\mathrm{mm}$, flat, asymmetric, spreading, attenuate, often hirsute on the exterior, especially towards the attenuate base. Petals adnate to the dorsal sepal, lanceolate, $4.5-8.4 \times 2.2-3.9 \mathrm{~mm}$, expanded at the outer margin towards the base becoming broadly falcate and from that point narrowing towards the obtuse apex. Lip ligulate to narrowly lanceolate, $5.3-10.1 \times 1.1-2.9$ $\mathrm{mm}$, a little narrowed toward the middle, with more or less pronounced lateral lobes near the base ranging from minutely expanded through lobular to dentate, tip sub-acute to attenuate; spur curved to sigmoid, 8.5 $19.3 \times 1.9-3.1 \mathrm{~mm}$, parallel with the ovary first becoming more pendent, tubular at the base then expanded, then narrowing into a more or less curved tip. Column $2-3.9 \times 1.7-2.8 \mathrm{~mm}$, with distinct rostellum arms, the anther loculi subglobose, staminodes small, slightly protruding below the lateral lobes of the rostellum, rostellum deeply notched in the middle, mid-lobe reduced to a small swollen blade, lateral arms c. $1 \mathrm{~mm}$ long, thick, incurved, the caudicles of the pollinia ending in a distinct viscidium. Fig. 13.

RECOGNITION. With its small mid-lobe of the rostellum and distinct elongate anther canals, Cynorkis nutans belongs in sect. Imerinorchis H.Perrier ex Hermans (Hermans et al. 2007: 290). It is recognised by its large leaf, tall hirsute inflorescence with a prominent lower peduncle sheath, the ovary and flowers hirsute on the exterior, the dorsal sepal and the petals forming a hood over the column, the flat, spreading, asymmetric, broadly lanceolate to ovate lateral sepals, and ligulate lip with small lobes at the base and a curved spur which is thickened around the middle.

It is similar in habit and lip shape to Cynorkis zaratananae Schltr. (Schlechter 1924: 75) but that species has a longer leaf petiole, slightly smaller flowers by c. $1 / 3$ and shorter spur, inflated at the tip (vs narrowing). It has a similar hirsute inflorescence and flowers and a similar lip shape to $C$. rosellata (Thouars) Bosser (1997: 188) and C. saxicola Schltr. (Schlechter 1924: 70) but those species have several leaves arranged in a rosette (vs single), slightly smaller flowers with a shorter spur half the length of the ovary (vs about the same length) which is thickened towards the tip (vs narrowing).

DISTRIBUTION. Widespread in Madagascar, mainly in the Eastern forest but also in the north and south, the Comoros (on Ngazidja [Grande Comore], Nzwani [Anjouan] and Mayotte). Records from Mauritius and Réunion are referable to Cynorkis inermis (Thouars) Hermans \& P.J.Cribb (Hermans et al. 2017: 28).

SPECIMENS EXAMINED. MADAGASCAR. Andrangoloaka, comm. 1880, Parker s.n. (K!); S Betsileo, Ankafina forest, March 1881, Hildebrandt 4204 (W! R14896); Imerina, rec. Nov. $1881, R$. P. Campenon s.n. (P00102291!); Imerina, 1881, Deans Cowan s.n. BM000911499!); Central, comm. Oct. 1882, Baron 1703 (lectotype BM000032250!; isolectotype K000415611!; P00102284!); April 1890, Scott Elliot s.n. K000415612!; Mandraka valley, Oct. 1905, C. d'Alleizette 478 (P00102299!); Manongarivo massif, c. $1500 \mathrm{~m}$, May 1909, Perrier 1941 (P000102309!); Andringitra, 1600 m, Sept. 1911, Perrier 8005 (P00102310!); E, Maningory basin, 700 m, Sept. 1912, Perrier 11377 (P00102311!); Analamazaotra, 1000 m, Aug. 1924, Humbert 2266 (P00102307!); Mt Ambre, Sept. 1926, Perrier 17733 (P00102296!, P102297!); S of Fianarantsoa, $1000 \mathrm{~m}$, Oct. 1926, Decary 5834 (P00102303!); East, between Moramanga \& Anosibe, eastern forest, on trunks amongst moss, c. $600 \mathrm{~m}$, Oct. 1927, Perrier 18028 (P00102312!, P00102313!); Fort-Dauphin distr., Col de Manangotry, 600 - 700 m, Aug. 1932, R. Decary 10355 (P00102286!); Matitantana, Tsianovoha forest, Sept. 1934, Heim s.n. (P00102304!); Andrangovalo massif, 1200 - 1400 m, Oct. 1937, Humbert E Cours 17784 (P00102288-90!); S of Moramanga, Sept. 1942, Decary 18419 (holo. P00102285!); Montagne d'Ambre forest, 1000 - 1200 m, Oct. 1944, Homolle 44 (P00102305-6!); Marojejy massif, 1000 m, Nov. - Dec. 1959, Humbert Eं Saboureau 31479 (P00102308!); Ankeramadinika, Aug. 1962, Bosser 16214 (P00102300!); road to Lakato, 

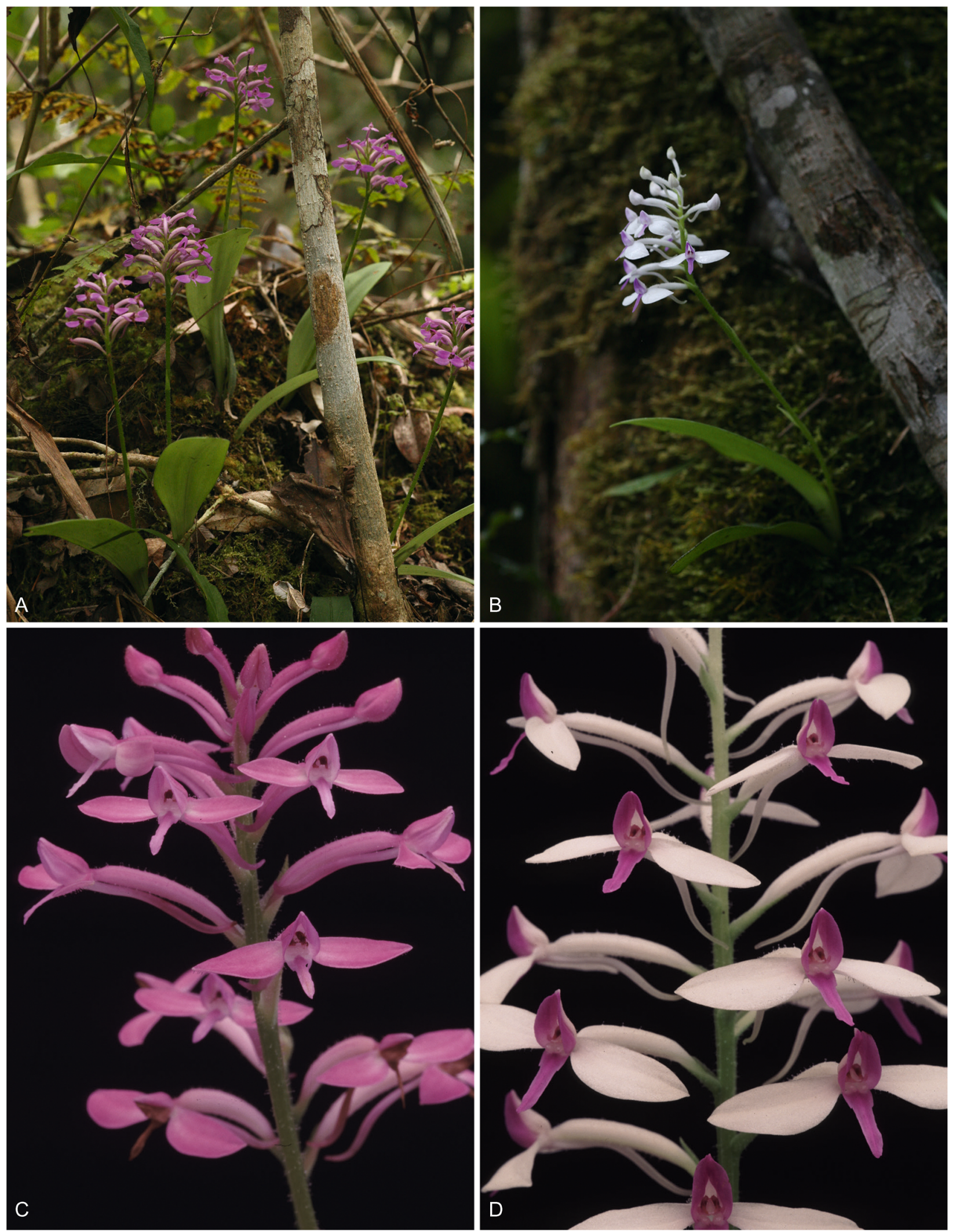

Fig. 13. Cynorkis nutans. A \& B plants in habitat; C \& D rachises. PHOTOS: JOHAN HERMANS. 
Aug. 1963, Bosser 17233 - 4 (P00102301 - 2!); Mt d'Ambre, 1200 - 1300 m, Nov. - Dec. 1964, Morat 1211 (P!); W of Ranomafana, 900 - 1100 m, Sept. 1992, Malcomber E $\mathcal{F}^{2}$ Rakoto 1554 (G!, K!, MO); Montagne d'Ambre, 1400 - 1475 m, April 1993, Malcomber et al. 22331 (K!, MO!); Fianarantsoa, Ranomafana S of Ambohimiera, 880 - 1100 m, Sept. 1993, Kotozafy $\mathcal{E}^{\circ}$ Randriananantena 240 (K!, MO); Antananarivo prov, Ankazobe, Hort., 1993, Hermans 2550 (K!); Toamasina prov., nr Maromiza, 1180 m, Jan. 2000, Hermans 5102 (K!); Toamasina prov., road to Lakato, $1043 \mathrm{~m}$, Feb. 2000, Hermans 5195 \& 6615 (K!); Toamasina prov., Andasibe area, 1229 m, Sept. 2000, Hermans 5022 (K!); Antsiranana, Andapa, Doany, Betsomanga, Marojejy, 1250 m, Oct. 2001, Gautier et al. LG3942 (G!); Fianarantsoa, Atsimo-Atsinanana, SW Befotaka, 1228 m, Sept. 2005, Toamasina, Lakato, Manasamena, 1064 m, Sept. 2007, Razanatsima et al. 417 (MO, P!, TAN!); Rakotovao et al. 2015 (MO, P!, TAN!); Hermans 5022 (K!); Toamasina prov., Andasibe area, Sept. 2007, Hermans 6768 (K!); Antsiranana, Montagne d'Ambre, 1460 m, Nov. 2007, Gautier et al. 5113 (G!, K!, MO, P!, TEF, WAG); Antsiranana, Daraina, forêt de Binara, 1015 m, Nov. 2005, Nusbaumer Ẽ Ranirison 1577 (G!); Alaotra Mangoro, Ambatovy. Ampirarazona forest, $1072 \mathrm{~m}$, Sept. 2008, Antilahimena et al. 6523 (MO, P!, TAN!); Montagne d'Ambre area, Hermans 2776 (K!); AlaotraMangoro, Ambatovy, 1141 - 1222 m, Sept. 2017, Ambatovy Spirit Collection, 3264A7115 - 3268A7115 \& 3711A6515 (TAN!); Maralambo, Herb. Inst. Sc. Mad. 822 (TAN!); Andapa, Duran 1039 (P00102287!); Montagne d'Ambre, Saboureau s.n. (P00102314!); Mora, Anosibe, Millot. 334 (TAN!). COMOROS. Mayotte, Humblot 209 (1209) (W! R5342); (P00102270!, P00102271!, P00102272!, BM000034836!); Mayotte, Combani forest, Sept. 1884, Humblot 1320 (BM!, W!); Grande Comore, May 1886, Humblot 1520 (P00102273 - 5!) Grande Comore, May 1886, Humblot 1520 (P00102273 - 5!); Grande Comore, La Convalescence to Boboni, Sept. 1958, Benson s.n. (BM000034808!, P00102276!); Anjouan, Mt Tingui, Oct. 1959, Benson 145 (BM!, TAN!); Grande Comore, Karthala Forest, 120 m, Sept. 1996, Moulaert 019 (P!); Grand Comore, Karthala, 1095 m, Aug. 2000, Brionnaud et al. 57 (CNDRS, K!, MO, P!); Mayotte, Chirongui, Mont Chongui, Feb. 2008, Barthelat et al. 1300 (P!); Karthala, piste de Boboni à Convalescence, Oct. 2008, 1200 - 1700 m, Pignal et al. 3350 (P!); Hort., Hermans 4392 (K!).

HABITAT. Terrestrial, epiphyte or lithophyte in evergreen forest, montane forest, lichen forest, in humus and moss, generally close to the ground on mossy tree trunks when epiphytic. $600-1700 \mathrm{~m}$.

CONSERVATION STATUS. Cynorkis nutans is widespread from Northern to Southern Madagascar in Diana, Sava, Analamanga, Alaotra-Mangoro, VatovavyFitovinany, Haute-Matsiatra and Anosy regions in Antsiranana, Antananarivo, Toamasina and Toliara provinces. It also occurs in the Comoros. The extent of occurrence (EOO) is estimated to be largely more than $20,000 \mathrm{~km}^{2}$. In addition, the species is located in many protected areas such as Analamazaotra-Mantadia, Marojejy, Montagne d'Ambre, Ranomafana. Part of the population may be threatened by habitat destruction due to charcoal production, firewood collection, agricultural clearing but these may not affect the survival of this species. Cynorkis nutans is therefore assessed as Least Concern (LC).

FLOWERING TIME. August to April but mainly September to December.

ETYMOlOGY. Campenoni refers to Pierre Campenon (1844 - 1909), a Catholic missionary who found the type of the variety; gaesiformis refers to the halberd gaesum spear-shape of the lip; galeata refers to the helmet-shape of the joined dorsal sepal and petals; nutans refers to the loosely nodding head of flowers as perceived by Ridley; pallens is derived from pallidus referring to the pale colour of the flowers; stenoglossa refers to the narrow lip.

NOTES. The species was first described as Habenaria nutans by Ridley in the Journal of the Linnean Society, Botany, based on a paper read to the Society in January 1885. The volume (21) itself is dated 1886 on the title-page but the following page lists the actual dates of publication with Ridley's paper being effectively published on April 29 ${ }^{\text {th }} 1885$. In the protologue Ridley mentioned three different collections from Madagascar: 'Central, Baron no 1703; Imerina, Deans Cowan Herb. Brit. Mus. and Andrangoloaka, Parker! Herb. Kew'. Later the same year H. G. Reichenbach $f$. described Cynorkis galeata in Flora, with the particular issue (31) dated 21 October 1885. Reichenbach cited specimen Humblot 209, collected on Mayotte. The holotype in W consists of two plants accompanied by a sketch of the flower and a detailed manuscript description by Reichenbach; there are four other sheets at BM and P. The P specimen is also labelled '1209'; Humblot's collection numbers were preceded by ' 1 ' in label transcriptions, following a re-numbering by Humbert in P. In 1893 Kraenzlin (: 63) described C. stenoglossa, based on a Hildebrandt specimen from Central Madagascar: the $\mathrm{W}$ specimen is labelled in error as Arnottia inermis but seen by Kraenzlin in 1938; it is likely that other material in $\mathrm{B}$ was destroyed; there are several specimens in $\mathrm{P}$ (Perrier 1941, 11377, 18028) annotated as syntypes, in error. Ridley's Habenaria nutans was transferred to the genus Cynorkis by Perrier in 1936 (: 582). In 1939 Perrier referred to unpublished 1931 names of C. nutans var. campenoni and C. stenoglossa var. pallens, both being validated by Hermans in 2007. The type material in $\mathrm{P}$ of C. stenoglossa var. pallens consists of two sheets of Perrier 17733, clearly labelled as 'type' (P00102296) and 'isotype' 
Table 4. Summary of measurements and characteristics of specimens of Cynorkis gaesiformis, C. galeata, C. nutans, C. nutans var. campenoni, C. stenoglossa and C. stenoglossa var. pallens.

\begin{tabular}{|c|c|c|c|c|}
\hline & C. gaesiformis & C. galeata & C. nutans \& vars & C. stenoglossa \& vars \\
\hline $\begin{array}{l}\text { Plant height } \\
(\mathbf{c m})\end{array}$ & $25-30$ & 25 & $15-25$ & $15-25$ \\
\hline Leaf & oblong, $16 \times 4 \mathrm{~cm}$ & $\begin{array}{l}\text { oblong, } 10-16 \times 3-5 \\
\text { cm }\end{array}$ & $\begin{array}{l}\text { elliptic-elliptic, } 10-14 \times 2.5- \\
3.8 \mathrm{~cm}\end{array}$ & oblong, $8-12 \times 2.5-3 \mathrm{~cm}$ \\
\hline Inflorescence & $\begin{array}{l}32 \mathrm{~cm}, \\
\text { hirsute }\end{array}$ & $\begin{array}{l}17-20 \mathrm{~cm} \\
\text { hirsute }\end{array}$ & $\begin{array}{l}26 \mathrm{~cm}, \\
\text { glandular-hirsute }\end{array}$ & $\begin{array}{l}6-12 \mathrm{~cm}, \\
\text { glandular-hirsute }\end{array}$ \\
\hline $\begin{array}{l}\text { Floral bracts } \\
\quad(\mathbf{m m})\end{array}$ & $5 \times 2$ & $5-8 \times 2$ & $5-9 \times 1.5-2$ & $5-9 \times 1.5 \times 2$ \\
\hline Dorsal sepal & $\begin{array}{l}5.2-3 \mathrm{~mm} \\
\text { hooded }\end{array}$ & $\begin{array}{l}6-8.2 \times 2.1 \times 3.5 \mathrm{~mm}, \\
\text { hooded }\end{array}$ & $\begin{array}{l}4.5-7.5 \times 2-3 \mathrm{~mm} \\
\text { hooded }\end{array}$ & $\begin{array}{l}4.5-8 \times 2-3 \mathrm{~mm} \\
\text { hooded }\end{array}$ \\
\hline $\begin{array}{l}\text { Lateral } \\
\text { sepals }\end{array}$ & $\begin{array}{l}9.2-11 \times 4-5.2 \\
\text { mm, asymmetric }\end{array}$ & $\begin{array}{l}7.5-12 \times 4.2-6 \mathrm{~mm}, \\
\text { semi-oval }\end{array}$ & $\begin{array}{l}7-14 \times 4-7 \mathrm{~mm} \\
\text { semi-orbicular }\end{array}$ & $\begin{array}{l}7.5-16 \times 4-8 \mathrm{~mm} \\
\text { semi-orbicular }\end{array}$ \\
\hline Petals (mm) & $5 \times 2.5$ & $6-8.6 \times 2-3$ & $4.5-8 \times 2-4$ & $5-8 \times 2-4$ \\
\hline Lip & $\begin{array}{l}6-10 \times 2 \mathrm{~mm}, \\
\text { ligulate halberd } \\
\text { shape at base }\end{array}$ & $\begin{array}{l}6-10 \times 1-2.1 \mathrm{~mm}, \\
\text { ligulate, dentate at ba- } \\
\text { se }\end{array}$ & $\begin{array}{l}5.6-9 \times 1.5-2 \mathrm{~mm}, \\
\quad \text { ligulate, lobular at base }\end{array}$ & $\begin{array}{l}5-10 \times 1-3.8 \mathrm{~mm} \text {, } \\
\text { narrow ligulate with basal } \\
\text { teeth }\end{array}$ \\
\hline Spur & $\begin{array}{l}\text { c } 15 \times 1 \mathrm{~mm} \text {, } \\
\text { thickened in the } \\
\text { middle }\end{array}$ & $\begin{array}{l}15-19 \times 0.7-1 \mathrm{~mm} \text {, } \\
\text { sigmoid, expanded in } \\
\text { the middle }\end{array}$ & $\begin{array}{l}11-20 \times 1-1.2 \mathrm{~mm} \text {, curved, } \\
\text { expanded in the middle }\end{array}$ & $\begin{array}{l}8.5-14 \times 1 \mathrm{~mm} \\
\text { expanded in the middle }\end{array}$ \\
\hline Column (mm) & $2 \times 2.1$ & $3-3.5 \times 2-3.2$ & $2-4 \times 1.5-2$ & $2-4 \times 2$ \\
\hline Distribution & $\begin{array}{l}\text { Madagascar: } \\
\text { Toamasina prov. }\end{array}$ & Comoros & $\begin{array}{l}\text { Madagascar: Antananarivo, } \\
\text { Antsiranana, Fianarantsoa, } \\
\text { Toamasina \& Toliara } \\
\text { provinces. Comoros }\end{array}$ & $\begin{array}{l}\text { Madagascar: Antananarivo, } \\
\text { Antsiranana, Fianarantsoa, } \\
\text { Toamasina provinces }\end{array}$ \\
\hline Altitude (m) & $600-800$ & $1095-1700$ & $600-1460$ & $600-1300$ \\
\hline $\begin{array}{l}\text { Flowering } \\
\text { time }\end{array}$ & Sept. & Aug. - Oct. & Aug. - April & Aug. - March \\
\hline
\end{tabular}

(P00102297). In 1951 Perrier (: 146) described C. gaesiformis from a collection by Decary in the Madagascan Highlands, the type sheet was annotated in 1950 as 'Cynosorchis caesumiformis sp. nov'. In 2005 Szlachetko transferred Cynorkis galeata, C. nutans and C. stenoglossa to his segregate genus Imerinorchis but did not include $C$. gaesiformis in the transfer.

Several authors and botanists have already indicated some similarity between Cynorkis gaesiformis, $C$. galeata, C. nutans and C. stenoglossa: the BM type specimen of C. galeata (Humblot 209) was annotated by Ridley as 'Habenaria nutans Ridley!'; Kraenzlin (1901: 920 \& 923) listed 'Cynorkis galeata Rchb.f. huc Habenaria nutans Ridley' under his Species subdubiae $v$. dubiae, Bosser determined the Decary 18419 type specimen of C. gaesiformis as C. nutans in 1968 and Hervouet (2018: 299) remarked that C. galeata, $C$. nutans and $C$. stenoglossa are to be compared. Following field observations and comparing all the available herbarium material identified under these four names and their varieties it has become clear that they are all part of one variable species with Ridley's C. nutans having priority over Reichenbach's C. galeata by just a few months, C. gaesiformis and C. stenoglossa are later additions of 1893 and 1951 respectively. Table 4 shows the great range in size of plant and flower segments of the different species and varieties but also indicates their overlapping characteristics; field observations have also shown great variations within colonies. Plants consistently have a single (rarely two), comparatively large leaf, a long hirsute inflorescence, an hirsute ovary and exterior of the flower, broad flat lateral sepals which are spreading and asymmetric, a ligulate lip which has variable but always small lobes at the base, a more or less sigmoid spur which is thickened in the middle and a rostellum with a reduced midlobe and separate incurved arms. Colour of the flowers is also very variable and may have led to some of the proliferation of names; field observations and photographic records have shown that there are a number of consistently different colour forms but it has also shown that the diverse colour variations are mixed within colonies and localities (see Fig. 13).

Following its general plant and flower morphology, Cynorkis inermis (Thouars) Hermans \& P.J.Cribb (Hermans et al. 2017: 28) from Mauritius and Réunion could also be considered part of this species but the lack of a spur makes it distinct. A few plants of $C$. inermis have been found on Réunion that have a short spur or remnant thereof (Bernet 2010: 122 \& pers. comm. and Szelengowicz \& Tamon 2013: 277) but the lack or reduction of a spur indicates a change in pollinator interaction and its endemism to the islands of Mauritius and Réunion warrant its recognition as a distinct species. The genetics and 

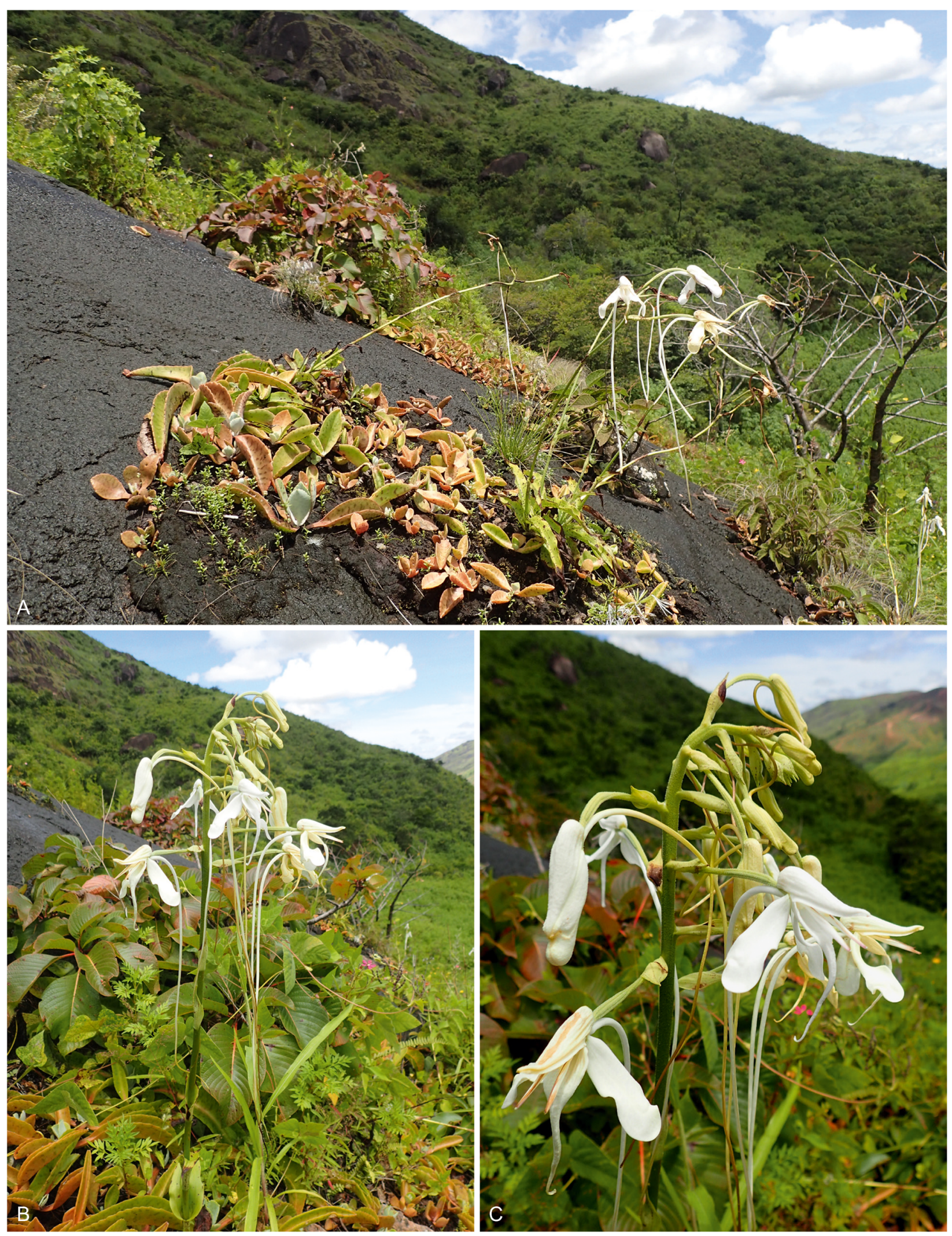

Fig. 14. Cynorkis mammuthus. A \& B plants in habitat; C rachis. PHOTOS: ANTON SIEDER. 
nomenclature of this species are discussed in Hermans et al. (2017: 27).

\section{Notes on Cynorkis mammuthus}

Cynorkis mammuthus Hermans \& P.J.Cribb (Hermans et al. 2017: 13), described recently from northern Madagascar, was based on a herbarium specimen, without much information, collected 25 years ago and consisted of part of an inflorescence only. In March 2019, a team from the University of Vienna and the Parc Botanique et Zoologique de Tsimbazaza Antananarivo, visited localities in $\mathrm{N}$ Madagascar and discovered it flowering in the Antsohihy area, not far from its type locality. This gives the opportunity to add more information to the description of the species, especially details about the plant, colour of the flowers and the lengthening of the spur.

Cynorkis mammuthus Hermans EF P.J.Cribb (Hermans et al. 2017: 13). Type: Madagascar, Mahajanga prov., road to Antsohihy, near Anjalazala, fl. Feb. 1994, Hermans 2699 (holotype K!).

Erect terrestrial or lithophytic plant, up to $75 \mathrm{~cm}$ high, including the inflorescence. Tubers $2-3$, elongate, clustered, surface velvety; roots a little hairy, fleshy, wiry c. $2 \mathrm{~mm}$ in diam. Stem elongate, dark green, c. 10 $-20 \mathrm{~cm}$ long, $8-18 \mathrm{~mm}$ in diam., enclosed by $1-2$ leaf-like sheaths and the basal leaf petiole; 3 - 4 large distant opposite leaves, followed by $2-4$ leaf-like sheaths above, decreasing in size. Leaves obliquely lanceolate, narrowed at the base into a long funnelshaped petiole annular at the base, with a strong midvein and $2-3$ parallel veins, $5-12 \mathrm{~cm}$ long, $2.5-$ $6.5 \mathrm{~cm}$ wide, leaves and leaf sheaths pale green spotted with brownish-maroon. Inflorescence emerging from the centre of the developed growth, dark green becoming paler towards the rachis, hirsute towards the apex, up to $40 \mathrm{~cm}, 1.9-3.5 \mathrm{~mm}$ in diam., with $2-$ 3 lanceolate leaf-like sheaths strongly amplectant towards the base, caudate at the tip, c. $2-4.5 \mathrm{~cm}$ long, $1 \mathrm{~cm}$ wide; rachis up to $20 \mathrm{~cm}$, densely hirsute, somewhat ridged, lengthening as the flowers open, laxly 11 - 20-flowered; floral bracts funnel-shaped, serrate-hirsute at the margin, dorsally keeled, acuminate, then apiculate at the apex, about $1 / 4$ the length of the ovary 21 - $28 \mathrm{~mm}$ long, $8-14 \mathrm{~mm}$ wide; pedicel with ovary densely hirsute, almost straight, $60-72 \mathrm{~mm}$ long, $1.8-2.2 \mathrm{~mm}$ wide. Flowers overall c. $4.5-6 \mathrm{~cm}$ long, $2.9-4 \mathrm{~cm}$ wide, not including the spur, at first yellowish-green then becoming pure white on opening, tips of the rostellum arms pale pink, pollinia caudicles brown. Dorsal sepal $32-37 \times 14-18 \mathrm{~mm}$ when flattened, forming a hood with the petals arching over the column, gibbose, expanded and hirsute at the base. Lateral sepals spreading, oblongelliptic with a distinctive notched wing on the upper margin towards the tip, $29-35 \times 12-15 \mathrm{~mm}$. Petals appressed to the inside of the dorsal sepal margins, linear-lanceolate, $31-35 \times 2.5-2.9 \mathrm{~mm}$. Lip entire, oblanceolate, naviculate, acuminate at the tip, $36-41$ $\times 12$ - $16 \mathrm{~mm}$; spur down-curved then pendent, subulate, lengthening with age $10.5-27 \mathrm{~cm}$ long, c. $2 \mathrm{~mm}$ in diam. Column in an angular plane $33-$ $36 \mathrm{~mm}$ long, 9 - $12 \mathrm{~mm}$ wide, with two very long rostellum arms for more than half its length, a small nose-like mid-lobe, staminodes towards the base, forming triangular auricles, anther loculi ovate, pollinia including the long caudicle c. $26 \mathrm{~mm}$ long. Fruit fusiform, densely hirsute, c. $6 \times 0.5 \mathrm{~cm}$. Fig. 14 .

SPECIMENS EXAMINED. MADAGASCAR. Mahajanga prov., road to Antsohihy, fl. Feb. 1994, Hermans 2699 (holotype K!); Befandriana, Feb. 1942, Jard. Bot. Tana 6242 (P!); near Antsohihy, 257 m, 22 March 2019, T. Eं C. Sieder, D. Prehslet, W. Knirsch Eे J. Andriantiana 7849 (W!).

HABITAT. In full sun on rock, in a thin layer of humus and moss. Short evergreen scrubland with Kalanchoe spp. and other geophytes. It is interesting to note that the spotted foliage of Cynorkis mammuthus is somewhat similar to that of Kalanchoe gastonis-bonnieri R.Hamet \& H.Perrier (1912: 364) (Crassulaceae), with which it grows together.

CONSERVATION STATUS. Cynorkis mammuthus is endemic to Madagascar, restricted to the Sofia region in Mahajanga province at low elevation. It is only known from a few individuals, the Area of Occupancy is estimated to be less than $500 \mathrm{~km}^{2}$, in three unprotected areas. The species is threatened by habitat degradation due to frequent fires. Cynorkis mammuthus is therefore assessed as Endangered EN, according to the IUCN Red List Categories and Criteria. Further research is needed to check the population size and status.

\section{Acknowledgements}

We are most grateful to the directors and staff at BM, BR, BRLU, DBN, G, HEID, K, M, MO, P, SZU, TAN, TEF, W, WU, M, SZL, ZSS and their relevant libraries. We would like to thank the anonymous reviewers for their constructive suggestions and corrections, Judi Stone for the detailed drawings, Julian Shaw for taxonomic advice and Michael Kiehn for his support. We are also very grateful to Solo 
Rapanarivo, head of the flora department at PBZT Antananarivo, for his permission to use the collection at the PBZT herbarium and for providing the necessary collecting authorisation.

Open Access This article is licensed under a Creative Commons Attribution 4.0 International License, which permits use, sharing, adaptation, distribution and reproduction in any medium or format, as long as you give appropriate credit to the original author(s) and the source, provide a link to the Creative Commons licence, and indicate if changes were made. The images or other third party material in this article are included in the article's Creative Commons licence, unless indicated otherwise in a credit line to the material. If material is not included in the article's Creative Commons licence and your intended use is not permitted by statutory regulation or exceeds the permitted use, you will need to obtain permission directly from the copyright holder. To view a copy of this licence, visit http://creativecommons.org/ licenses/by/4.0/.

\section{References}

Baillon, M. H. (1879). Sur Quelques genres de Rubiacées dont la place est douteuse. Bull. Mens. Soc. Linn. Paris 1: 198 - 200.

Bernet, P. (2010). Orchidées de la Réunion. Naturae Amici éditions.

Bosser, J. (1969). Contribution à l'Étude des Orchidaceae de Madagascar X. Adansonia 9: 343 - 359.

(1980). Contribution à l'Étude des Orchidaceae

de Madagascar. Adansoni, 20: 257 - 261.

(1997). Contribution à l'étude des Orchidaceae de Madagascar et des Mascareignes. XXVII. Adansonia 19: 181 - 188.

(1998). Contribution à l'étude des Orchidaceae

de Madagascar et des Mascareignes. XXVIII. Adansonia 20: 281 - 283.

(2002). Contribution à l'étude des Orchidaceae de Madagascar et des Mascareignes. XXXII. Adansonia 24: 21 - 25.

(2015). Description de trois Cynorkis Thouars nouveaux (Orchidaceae) du Nord de Madagascar. Adansonia 37: 19 - 23.

\& Lecoufle, M. (2011). Les Orchidées de Madagascar. Biotope, Mèze.

\& Veyret, Y. (1970). Contribution a l'Étude des Orchidaceae de Madagascar XIII. Adansonia 10: 213 - 217.

Cribb, P. \& Hermans, J. (2009). Field Guide to the Orchids of Madagascar. Kew Publishing, Royal Botanic Gardens, Kew.
Durand, T. A. \& Schinz, H. (1895). Conspectus Florae Africae 5. Charles van der Weghe, Bruxelles.

Frappier C. de Monbenoist (1880). Orchidées de l'Île de la Réunion, Catalogue des Espèces Indigènes Découvertes Jusqu'à ce Jour. Réunion.

in J. E. de Cordemoy (1895). Flore de l'Ile de la Réunion. Orchidées: 165 - 262. Klincksieck, Paris.

Govaerts, R., Bernet, P., Kratochvil, K., Gerlach, G., Carr, G., Alrich, P., Pridgeon, A. M., Pfahl, J., Campacci, M. A., Holland Baptista, D., Tigges, H., Shaw, J., Cribb, P., Kreuz, K. \& Wood, J. (2019). World Checklist of Selected Plant Families. Facilitated by the Royal Botanic Gardens, Kew. Published on the Internet: http://apps.kew.org/wcsp/.

Hamet, R. \& Perrier, H. (1912). Contribution a l'étude des Crassulacées Malgaches. Ann. Sci. Nat. Bot. 10: $361-377$.

Hermans, J., Andriantiana, J. L., Sieder A., Kiehn, M., Cribb, P., Rajaovelona, L. \& Gardiner, L. (2017). New species and nomenclatural changes in Cynorkis (Orchidaceae: Orchidoideae) from Madagascar and the Mascarenes. Kew Bull. 72, 38: 1 - 31 .

\& Cribb, P. J. (2007). Cynorkis in Madagascar. Orchid Rev. 115: 248 - 255.

\& _ (2014). New species and new names in Malagasy orchids (Orchidaceae). Kew Bull. 69, 9517: $1-16$

, Hermans, C., Du Puy, D., Cribb, P. \& Bosser, J. (2007). Orchids of Madagascar $2^{\text {nd }}$ edition. Kew Publishing. Royal Botanic Gardens, Kew.

\& Rajaovelona, L. (2019). A new Natural Hybrid in Cynorkis from Madagascar. Amer. Orchid Soc. Bull. 88: 547 - 550 .

Hervouet, J-M. (2018). A la recherche des Orchidées de Madagascar. Biotope, Mèze.

Humbert, H. (1939). Flore de Madagascar. 49e. Famille. Orchidées. Tananarive Imprimerie Officielle, Madagascar.

IUCN (2012). IUCN Red List Categories and Criteria: Version 3.1. 2nd edition. Gland and Cambridge.

Kraenzlin, F. (1893). Orchidaceae Africanae VII. Bot. Jahrb. Syst. 33: $53-75$.

(1898 - 1901). Orchidacearum Genera et Species. 1. Mayer \& Mueller, Berlin.

Lindley, J. (1835). Orchideae Tribe IV. Ophrydeae. Genera and species of Orchidaceous plants. Ridgeways, London.

Perrier de la Bâthie, H. (1930). Catalogue des Plantes de Madagascar publié par L'Académie Malgache. Orchidaceae d'après $R$. Schlechter. Colonie de Madagascar et Dépendances, Paris.

(1931, unpublished). Arch. Bot. Bull. Mens. 5: 36, 48, 72.

(1936). Notes sur quelques Habenaria de Madagascar. Bull. Soc. Bot. France 83: 579 - 585. 
(1939). Orchidaceae. In: H. Humbert, Flore de Madagascar. 49e. Famille. - Orchidées. Tananarive Imprimerie Officielle, Madagascar.

(1951) Orchidées de Madagascar et des Comores. Notul. Syst. (Paris) 14: 138 - 165.

Reichenbach, H. G. f. (1885). Comoren-Orchideen Herrn Léon Humblot's. Flora 68: 377 - 382.

(1888). Orchideae describuntur. Flora 71: 535 544.

Ridley, H. N. (1883). Descriptions and Notes on new or rare Monocotyledonous Plants from Madagascar, with one from Angola. J. Linn. Soc., Bot. 20: 329 - 338.

(1885). The Orchids of Madagascar. J. Linn. Soc., Bot. 21: 456 - 523.

(1886). On Dr. Fox's collection of Orchids from Madagascar, along with some obtained by the Rev. R. Baron from the same Island. J. Linn. Soc. Bot. 22: 116 - 127.

Schlechter, R. (1913). Orchidacées de Madagascar. Orchidaceae Perrieranae Madagascarienses. Ann. Mus. Colon. Marseille, sér. 3, 1: 148 - 202.

(1915). Kritische Aufzählung der bisher von Madagaskar, den Maskarenen, Komoren und Seychellen bekantgewordenen Orchidaceen. Beih. Bot. Centralbl. 33: 390 - 440.

(1924). Orchidaceae Perrieranae. Repert. Spec. Nov. Regni Veg. Beih. 33: 1 - 240.

Szelengowicz, M. \& Tamon, J. M. (2013). Les Orchidées des Mascareignes, Printec. Seychelles.
Szlachetko, D. (2005). Habenaria - Beitrage zu einer Revision der Subtribus (12). Orchidee (Hamburg) 56: $68-70$.

\& Kras, M. (2006). Matériaux pour la révision des Habenariinae (Orchidaceae, Orchidoideae) - 6 . Richardiana 6: 139 - 146.

Thouars, A. du Petit (1822). Histoire particulière des Plantes Orchidées recueillies sur les trois Îles Australes d'Afrique. Bertrand, Treuttel \& Wurtz, Paris.

Toilliez-Genoud, J. \& Bosser, J. (1961). Contribution à l'étude des Orchidaceae de Madagascar et des Mascareignes. IV. Adansonia 1: 100 - 105.

\& ___ (1962). Contribution à l'étude des Orchidaceae de Madagascar et des Mascareignes. III. Naturaliste Malgache 13: 25 - 30.

Turland, N. J., Wiersema, J. H., Barrie, F. R., Greuter, W., Hawksworth, D. L., Herendeen, P. S., Knapp, S., Kusber, W.-H., Li, D.-Z., Marhold, K., May, T. W., McNeill, J., Monro, A. M., Prado, J., Price, M. J. \& Smith, G. F. (eds) (2018). International Code of Nomenclature for algae, fungi, and plants (Shenzhen Code) adopted by the Nineteenth International Botanical Congress Shenzhen, China, July 2017. Regnum Veg. 159. Koeltz. Glashütten. DOI https://doi.org/10.12705/Code.2018.

\section{Publisher's Note}

Springer Nature remains neutral with regard to jurisdictional claims in published maps and institutional affiliations. 